\title{
Arsenic trioxide inhibits the growth of cancer stem cells derived from small cell lung cancer by downregulating stem cell- maintenance factors and inducing apoptosis via the Hedgehog signaling blockade
}

\author{
Ke-Jie Chang ${ }^{1,2 \#}$, Ji-Zhong Yin ${ }^{1 \#}$, Hai Huang ${ }^{1}$, Bing Li ${ }^{1}$, Meng-Hang Yang ${ }^{3}$ \\ ${ }^{1}$ Department of Respiratory and Critical Care Medicine, Changzheng Hospital, Second Military Medical University, Shanghai, China; ${ }^{2}$ Department \\ of Medical Oncology, The Fifth Affiliated Hospital of Sun-Yat-Sen University, Zhuhai, China; ${ }^{3}$ Department of Oncology, Shanghai Pulmonary \\ Hospital, Tongji University School of Medicine, Shanghai, China \\ Contributions: (I) Conception and design: KJ Chang, MH Yang, B Li; (II) Administrative support: MH Yang, B Li; (III) Provision of study materials or \\ patients: KJ Chang, MH Yang, JZ Yin; (IV) Collection and assembly of data: KJ Chang, MH Yang, JZ Yin; (V) Data analysis and interpretation: All \\ authors; (VI) Manuscript writing: All authors; (VII) Final approval of manuscript: All authors. \\ \# These authors contributed equally to this work. \\ Correspondence to: Meng-Hang Yang. Department of Oncology, Shanghai Pulmonary Hospital, Tongji University School of Medicine, 507 Zhengmin \\ Road, Shanghai 200433, China. Email: feike_ymh@163.com. Bing Li. Department of Respiratory and Critical Care Medicine, Changzheng Hospital, \\ Second Military Medical University, 415 Fengyang Road, Shanghai 200003, China. Email: libing1962@smmu.edu.cn.
}

Background: Small cell lung cancer (SCLC) is the most deadly and aggressive type of primary lung cancer, with the 5-year survival rate lower than 5\%. The FDA has approved arsenic trioxide $\left(\mathrm{As}_{2} \mathrm{O}_{3}\right)$ for acute promyelocytic leukemia (APL) treatment. However, its role in SCLC-derived cancer stem cells (CSCs) remains largely unknown.

Methods: CSCs were enriched from SCLC cell lines by culturing them as spheres in conditioned serumfree medium. Then, qPCR, western blot, serial passage, limiting dilution, Transwell, and tumorigenesis assay were performed to verify the cells' stem phenotypic characteristics. Anticancer efficiency of $\mathrm{As}_{2} \mathrm{O}_{3}$ was assessed in these cells using CCK8, colony formation, sphere formation, flow cytometry, qPCR, western blot analysis in vitro, and tumor growth curve, immunofluorescence, and TUNEL staining analyses in vivo.

Results: The fifth-passage SCLC spheres showed a potent self-renewal capacity, higher clonal formation efficiency (CFE), SOX2, c-Myc, NANOG, and OCT4 levels, and invasion ability, and stronger tumorigenesis capacity than the parental SCLC cells, indicating that the SCLC sphere cells displayed CSC features. $\mathrm{As}_{2} \mathrm{O}_{3}$ inhibited the proliferation, clonality and sphere forming ability of SCLC-derived CSCs and suppressed the tumor growth of CSCs-derived xenograft tumors. $\mathrm{As}_{2} \mathrm{O}_{3}$ induced apoptosis and downregulation of SOX2 and c-Myc in vitro and in xenografts. Besides, SOX2 knockdown suppressed SCLC-derived CSCs to selfrenew and induced apoptosis. Mechanistically, expression of GLI1 (a key transcription factor of Hedgehog pathway) and its downstream genes increased in SCLC-derived CSCs, compared to the parental cells. $\mathrm{As}_{2} \mathrm{O}_{3}$ dramatically downregulated GLI1 and its downstream genes in vitro and in vivo. The GLI inhibitor (GANT61) recapitulated and enhanced the effects of $\mathrm{As}_{2} \mathrm{O}_{3}$ on SCLC-derived CSCs, including growth suppression, apoptosis induction, and GLI1, SOX2 and c-Myc downregulation.

Conclusions: Altogether, $\mathrm{As}_{2} \mathrm{O}_{3}$ effectively suppressed SCLC-derived CSCs growth by downregulating stem cell-maintenance factors and inducing apoptosis. These effects are mediated at least partly via the Hedgehog signaling blockade.

Keywords: Small cell lung cancer (SCLC); cancer stem cells (CSCs); arsenic trioxide; SOX2; Hedgehog signaling 
Submitted Mar 23, 2020. Accepted for publication Jul 09, 2020.

doi: $10.21037 /$ tlcr-20-467

View this article at: http://dx.doi.org/10.21037/tlcr-20-467

\section{Introduction}

Small cell lung cancer (SCLC), accounting for approximately $15 \%$ of lung cancer, is the deadliest and most aggressive primary lung cancer type, and it kills around 250,000 people per year worldwide (1). Diagnosed SCLC is usually widely metastatic, and the standard treatment is platinum-based chemotherapy with etoposide and radiotherapy (2). Although, SCLC patients initially respond well to cytotoxic therapy, tumor recurrence occurs in most patients. Due to the lack of effective drugs for second-line chemotherapy, the 5-year survival rate of SCLC patients is lower than $5 \%$ (3).

Recently, a small subset of tumor cells endowed with stem-cell properties, termed cancer stem cells (CSCs), were isolated from leukemia (4) and solid tumors including SCLC (5-7). CSCs from SCLC cell lines or tumor tissues grow as non-adherent spherical colonies under specified serum-free conditions, and they potently initiate tumor xenografts in immunocompromised mice $(6,7)$. CSCs have capacities to self-renew, differentiate into heterogeneous progeny, and initiate tumor formation (6). CSCs are responsible for SCLC invasion, metastasis, therapeutic resistance, and recurrence. Thus, efficient elimination of CSCs might be a more effective strategy to treat cancer than the current treatment methods.

Several studies reported that Hedgehog signaling plays a crucial role in SCLC pathogenesis. Shh and GLI1 protein expression was observed in SCLC tissues and cell lines, and the Smo inhibitor cyclopamine could inhibit the growth of SCLC cell lines (8). Activation of Hedgehog signaling promoted SCLC initiation and progression in Rb1-Trp53mutant mice models, and Hedgehog pathway blockade suppressed SCLC growth in mice $(9,10)$. Hedgehog signaling inhibition effectively prevented cancer recurrence after chemotherapy in SCLC mice models $(9,10)$.

Arsenic trioxide $\left(\mathrm{As}_{2} \mathrm{O}_{3}\right)$ was approved by the FDA to treat acute promyelocytic leukemia (APL). The safety of the drug at therapeutic concentration has been well demonstrated in clinical practice. In recent years, $\mathrm{As}_{2} \mathrm{O}_{3}$ has been shown to have anticancer activity in gliomas $(11,12)$, breast cancer $(13)$, hepatocellular carcinoma (14) and pancreatic cancer (15). Several studies demonstrated that $\mathrm{As}_{2} \mathrm{O}_{3}$ triggers pronounced cell death in SCLC cells via apoptosis or necrosis $(16,17)$. The inhibitory effects of $\mathrm{As}_{2} \mathrm{O}_{3}$ on SCLC growth were also seen in nude mice models (17-19), suggesting that $\mathrm{As}_{2} \mathrm{O}_{3}$ may be an effective drug for SCLC. Our preliminary study found that $\mathrm{As}_{2} \mathrm{O}_{3}$ can inhibit H446 cells from forming tumor spheres under serum-free conditions, reduce the expression of stem cell biomarkers CD133, SOX2 and OCT4, and inhibit GLI1 and its target genes (20). However, our previous study did not isolate CSCs from SCLC cell lines. The impacts of $\mathrm{As}_{2} \mathrm{O}_{3}$ treatment on SCLC stem cells in xenografts and the underlying molecular mechanisms are still largely undefined.

Here, we identified the stem phenotypic characteristics of CSCs derived from SCLC, investigated the therapeutic effects of $\mathrm{As}_{2} \mathrm{O}_{3}$ on these cells, and further explored the possible signaling pathway involved in this process.

We present the following article in accordance with the ARRIVE reporting checklist (available at http://dx.doi. org/10.21037/tlcr-20-467).

\section{Methods}

\section{Reagents}

For in vitro assays, $\mathrm{As}_{2} \mathrm{O}_{3}$ (SL Pharm, China) was dissolved in $1 \times$ phosphate-buffered saline (PBS) at a stock solution concentration of $1 \mathrm{mmol} / \mathrm{L}$. $\mathrm{As}_{2} \mathrm{O}_{3}$ was dissolved in normal saline (NS) for in vivo studies. GANT-61 $\left(\mathrm{C}_{27} \mathrm{H}_{35} \mathrm{~N}_{5}\right)$ was purchased from Selleck company (Shanghai, China). GANT-61 was prepared as stock solutions in ethanol before diluting in cell culture medium. The final ethanol concentration did not exceed $0.1 \% \mathrm{v} / \mathrm{v}$, and ethanol had no demonstrable effect on cell cultures.

\section{Cell culture}

The SCLC cell lines H446 and H209 were obtained from the Cell Bank of the Chinese Academy of Sciences (Kunming, China). Cell lines were authenticated by analyzing short tandem repeats (STR) by the FuHeng Cell Center (Shanghai, China). Cells were grown in DMEM/ F12 medium supplemented with $10 \%$ fetal bovine serum 
(FBS).

Cells were cultured in serum-free conditioned medium as previously reported to enrich CSCs from $\mathrm{H} 446$ and H209 (6,7). The serum-free conditioned medium consists of DMEM/F12 medium (Life Technologies, USA) supplemented with $20 \mathrm{ng} / \mathrm{mL}$ epidermal growth factor (EGF) (Invitrogen, USA), $20 \mathrm{ng} / \mathrm{mL}$ basic fibroblast growth factor (bFGF) (Invitrogen, USA), 2\% B27 supplement (Life Technologies, USA), $2 \mathrm{mM} \mathrm{L-glutamine} \mathrm{(Invitrogen,} \mathrm{USA),}$ and $1 \%$ Insulin-Transferrin-Selenium (ITS) (Invitrogen, USA) in ultra-low-adherent plates (Corning, USA). Culture medium was replaced twice a week, and CSCs were passaged every six to seven days.

\section{Limiting dilution analysis}

The first, second, third, fourth, and fifth-passage spheres and their parental cells were dissociated into single-cell suspensions. To obtain a single cell per well, 100 cells were cultured in $200 \mu \mathrm{L}$ serum-free conditioned medium mentioned above in a 96-well plate. After 14 days of culture, the number of tumor spheres formed in each well was evaluated under an inverted microscope (Leica, Germany). CFE was calculated using the following formula: CFE = the number of spheres formed/ the number of single cells plated $\times 100 \%$.

\section{Quantitative real-time PCR (qPCR)}

The total RNA was extracted from cells or tissues and then reverse transcribed to cDNA. RT-PCR analysis was performed using an Applied Biosystems Prism 7900 HT Sequence Detection System with Universal SYBR qPCR Master Mix (Vazyme, China). Primer sequences were shown in Table S1. The expression levels of each mRNA relative to the $\beta$-actin expression level were calculated based on the $2^{-\Delta \Delta C t}$ method.

\section{Western blot analysis}

Cells or tissues were lysed with cell lysis buffer containing phenylmethanesulfonylfluoride (PMSF). Proteins were electrophoretically transferred onto polyvinylidene fluoride (PVDF) membranes. Membranes were blocked with 3\% bovine serum album (BSA) in PBST for two hours before incubating overnight at $4{ }^{\circ} \mathrm{C}$ with primary antibodies. The primary antibodies were as follows: SOX2 (Abcam, UK), c-Myc (Abcam, UK), NANOG (Abcam, UK), OCT4
(Abcam, UK), GLI1 (Abcam, UK), Caspase-3 (Cene Tex, USA), PARP (CST, USA), and $\beta$-actin (ABclonal, USA). The membranes were rinsed, followed by incubation with the secondary antibody (Servicebio, China) and visualization of the bands using the ECL detection reagents.

\section{Transwell assay}

SCLC-derived CSCs or parental cells were dissociated into single-cell suspensions. The cells were resuspended in serumfree DMEM/F12 to a density of $5 \times 10^{4}$ cells $/ \mathrm{mL}$ in Transwell inserts (Corning, USA) in a 24-well plate. DMEM/F12 containing $10 \%$ FBS was added to the bottom of a $24-$ well plate. After incubating for 24 hours, the Transwell membranes were fixed with $4 \%$ paraformaldehyde before staining with crystal violet. The migrated cells on the lower of the Transwell membrane were counted under an inverted microscope in five random fields at $200 \times$ magnification.

\section{In vivo tumorigenesis analysis}

We evaluated the tumorigenicity of SCLC-derived CSCs and parental SCLC cells. Four-week-old male nude mice were purchased from and housed in the specific pathogen free (SPF) room of the Experimental Animal Center affiliated with the Second Military Medical University. The weight range of the nude mice is 18 to $22 \mathrm{~g}$. The animal study was approved by the Committee on Ethics of Biomedicine, Second Military Medical University (Reference Number: 20160218-8160110302). Animal welfare and experimental procedures were carried out in accordance with the Guide for the Care and Use of Laboratory Animals (Ministry of Science and Technology of China). SCLC-derived CSCs and parental cells were dissociated into single cell suspensions diluted in DMEM/ F12 medium mixed with Matrigel (BD Biosciences, USA). Then, they were subcutaneously implanted in the right and left flanks of nude mice, in varying amounts $\left(1 \times 10^{4}, 1 \times 10^{5}\right.$ or $1 \times 10^{6}$ cells). There were 5 nude mice in each group. Tumor growth was observed and recorded twice a week. The mice were sacrificed and the tumor tissues were collected after three months of growth. Hematoxylin and eosin (HE) staining was performed.

\section{Tumor sphere formation analysis}

SCLC-derived CSCs $\left(2 \times 10^{4}\right.$ per well) were seeded in $2 \mathrm{~mL}$ serum-free conditioned medium in low-adherent 6-well 
culture plates (Corning, USA) and treated with $0.5-4 \mu \mathrm{M}$ $\mathrm{As}_{2} \mathrm{O}_{3}$. Cells treated with vehicle were used as controls. After incubating at $37^{\circ} \mathrm{C}$ for five days, pictures were taken under a microscope and tumor spheres were counted in five separated $40 \times$ fields.

Then, SCLC-derived CSCs $\left(1 \times 10^{3}\right.$ per well $)$ were seeded in low-adherent 96-well plates (Corning, USA) in $200 \mu \mathrm{L}$ serum-free conditioned medium before treating with different concentrations of $\mathrm{As}_{2} \mathrm{O}_{3}$, GANT-61, or $\mathrm{As}_{2} \mathrm{O}_{3}+\mathrm{GANT}-61$. Cells treated with vehicle were used as controls. After incubation for five days, the number of tumor spheres was counted in five separated $100 \times$ fields.

\section{Tumor sphere recovery analysis}

SCLC-derived CSCs were treated with different concentrations of $\mathrm{As}_{2} \mathrm{O}_{3}(1-4 \mu \mathrm{M})$. After 72 hours, cells from each group were collected, digested into single cells, and stained with trypan blue. Subsequently, for each group, $2 \times 10^{4}$ viable cells per well were counted and seeded in low-adherent 6-well plates (Corning, USA) in serum-free conditioned medium without $\mathrm{As}_{2} \mathrm{O}_{3}$. After incubating at $37{ }^{\circ} \mathrm{C}$ for five days, pictures were taken under a microscope and the tumor spheres were counted in five separated $40 \times$ fields.

\section{CCK8 cell viability assay}

SCLC-derived CSCs $\left(1 \times 10^{4}\right.$ per well $)$ were seeded in 200 $\mu \mathrm{L}$ serum-free conditioned medium in 96-well culture plates before treating with $0.5-8 \mu \mathrm{M} \mathrm{As}_{2} \mathrm{O}_{3}$. Cells treated with vehicle were used as controls. After incubating at $37^{\circ} \mathrm{C}$ for 24, 48 or 72 hours, CCK8 reagent (Beyotime, China) was added and the absorbance at $450 \mathrm{~nm}$ was measured. The cell inhibition ratio (IR) was calculated using the following formula: $I R=(1-$ absorbance in the treated group/absorbance in the control group) $\times 100 \%$.

\section{Colony formation assay}

Zero-point sixty-five percent agarose in DMEM/F12 medium was overlaid on the bottom of plastic 6-well plates. Dissociated SCLC-derived CSCs $\left(2 \times 10^{4}\right.$ per well) were suspended in specified serum-free medium containing $0.35 \%$ agarose and placed on top of the bottom layer. Cells were treated with different concentrations of $\mathrm{As}_{2} \mathrm{O}_{3}(0-4 \mu \mathrm{M})$ for 14 days. Colony formation was analyzed under an inverted microscope by measuring the number of colonies in three random $\times 40$ fields per well.

\section{Cell cycle analysis}

SCLC-derived CSCs were treated with different concentrations of $\mathrm{As}_{2} \mathrm{O}_{3}(0-4 \mu \mathrm{M})$ for 24 hours. Cells were collected and dissociated using Accutase cell detachment solution (BD, USA) to obtain single cells. Cells were incubated with DNA staining solution and permeabilization solution (MultiScience, China) at $37{ }^{\circ} \mathrm{C}$ for $30 \mathrm{~min}$. The cell cycle was analyzed via flow cytometry with a FACS Calibur (BD, USA).

\section{Annexin V-FITC apoptosis analysis}

SCLC-derived CSCs were treated with varying concentrations of $\mathrm{As}_{2} \mathrm{O}_{3}$, GANT-61 or $\mathrm{As}_{2} \mathrm{O}_{3}+$ GANT-61 for 48 hours, and apoptosis was measured using the FITC Annexin apoptosis detection kit I (BD, USA). Briefly, cells were dissociated and resuspended in $1 \times$ binding buffer. Next, FITC Annexin V and PI were added, followed by incubation at room temperature for $15 \mathrm{~min}$. Data were analyzed using a flow cytometer.

\section{Lentiviruses and transfection}

Lentiviruses were produced in HEK-293T cells as previously described (21). Lentiviral vectors were GV248 vectors (GeneChem, China). LV-shSOX2-1 targets the sequence 5'-caGCTCGCAGACCT ACATGAA-3' and LV-shSOX2-2 targets the sequence 5'-gaAGAAGGATAAGTACACGCT-3'. Sequencing results are shown in Figure S1A,B. SCLC-derived CSCs were transfected with lentiviruses using Polybrene (GeneChem, China).

\section{In vivo animal models and treatment}

Four-week-old male nude mice were purchased from and housed in the SPF room of the Experimental Animal Center affiliated with the Second Military Medical University. The weight range of the nude mice is 18 to $22 \mathrm{~g}$. The animal study was approved by the Committee on Ethics of Biomedicine, Second Military Medical University (Reference Number: 20160218-8160110302). Animal welfare and experimental procedures were carried out in accordance with the Guide for the Care and Use of Laboratory Animals (Ministry of Science and Technology of China). The mice were subcutaneously inoculated in 
the right flanks with SCLC-derived CSCs $\left(1 \times 10^{6}\right.$ cells per mouse) in DMEM/F12 medium mixed with Matrigel (BD, USA). The tumor-bearing mice were randomly divided into three groups ( 7 mice per group) when the average tumor volume reached $60-70 \mathrm{~mm}^{3}$. The groups included one control (NS) group and two $\mathrm{As}_{2} \mathrm{O}_{3}$ groups (2.5 or $\left.5.0 \mathrm{mg} / \mathrm{kg} \mathrm{As} \mathrm{As}_{2}\right) . \mathrm{As}_{2} \mathrm{O}_{3}$ was dissolved in NS. All mice were treated by intraperitoneal injection once daily for 14 days. Tumor volume $(V)$ was measured every other day using caliper and calculated using the following formula: $V\left(\mathrm{~mm}^{3}\right)=\left(L \times W^{2}\right) / 2$, where $L=$ length $(\mathrm{mm}), W=$ width $(\mathrm{mm})$.

\section{Immunofluorescence}

The frozen tissue slices were fixed with $4 \%$ paraformaldehyde, blocked with blocking buffer for immunol staining (Beyotime, China) at room temperature, and incubated overnight at $4{ }^{\circ} \mathrm{C}$ with the following primary antibodies: SOX2 (Abcam, UK) and c-Myc (Abcam, UK). The slides were then incubated with the appropriate secondary antibody for one hour at room temperature. Alexa 488-conjugated or Cy3-conjugated goat antirabbit IgG (Servicebio, China) was used. Cell nuclei were counterstained with DAPI, and images were collected with a Leica fluorescence microscope. The ratio of $\mathrm{SOX} 2^{+}$or $\mathrm{c}-\mathrm{Myc}^{+}$cells were determined by counting positive-stained cells and total cells in four separated $\times 400$ fields of each tumor sample. Five tumor samples were analyzed in both $\mathrm{As}_{2} \mathrm{O}_{3}$ groups and control group.

\section{TUNEL stain}

The cryopreserved tissue sections were fixed with $4 \%$ paraformaldehyde, permeabilized with $0.3 \%$ Triton X-100 in PBS, and blocked with endogenous peroxidase blocking buffer. The sections were incubated with TUNEL reaction mixture (Roche, Switzerland) for one hour. The sections were rinsed and incubated with Converter-POD (Roche, Switzerland) at $37^{\circ} \mathrm{C}$ for $30 \mathrm{~min}$. The sections were colored with DAB substrate (Servicebio, China) and counterstained with hematoxylin. The ratio of apoptotic cells was determined under a light microscope by counting TUNEL positivestained cells and total cells in four separated $\times 400$ fields.

\section{Statistical analysis}

Results were analyzed using the SPSS 22.0 software program. Data were presented as the means \pm SD and analyzed using a two-tailed Student's $t$-test or one-way ANOVA. A repeated measure ANOVA was used to calculate the $\mathrm{P}$ values for tumor growth curves. $\mathrm{P}$ values $<0.05$ were considered statistically significant.

\section{Results}

\section{Sphere cells derived from $\mathrm{H} 446$ and $\mathrm{H} 209$ cell lines display CSC characteristics}

CSCs can form spherical colonies when cultured in specific conditions including serum-free medium and low adherence substrate (22). Cancer cell line-derived or primary tumorderived sphere cells exhibit powerful self-renewal capacity, tumor-initiating abilities, and they are more resistant to chemotherapy and radiotherapy $(23,24)$. To enrich CSCs, we grew the SCLC cell lines H446 and H209 in specified serum-free medium. After four to six days of culture, we observed that cells formed floating spheres of varying sizes (Figure 1A). These spheres were dissociated into single cells that could be passaged serially more than 30 times. By limiting dilution analysis, we examined the in vitro self-renewal ability of different-generation spheres and their parental cells. As shown in Figure 1B, as generations increased, the CFE of sphere cells was obviously elevated. In these two cell lines, the CFE of fifth-passage sphere cells were above $70 \%$.

We used qPCR and western blotting to verify that fifthpassage H446 spheres or H209 spheres exhibited higher expression of the stem cell transcription factors SOX2, OCT4, NANOG and c-Myc at the mRNA and protein levels compared with their parental cells (Figure 1C,D). However, we used qPCR and flow cytometry to show that the expression levels of the stem cell marker CD133, CD44, and Nestin did not increase in the fifth-passage H446 spheres or H209 spheres compared to their parental cells (Figure 1E,F,G). We also observed enhanced invading ability in the fifth-passage H446 spheres or H209 spheres compared to their parental cells (Figure 1H,I).

Analysis of tumorigenic ability in an immunodeficient mice is the standard method to for CSC identification (25). SCLC-derived sphere cells and parental cells were subcutaneously implanted in the right and left flanks of nude mice, in varying amounts $\left(1 \times 10^{4}, 1 \times 10^{5}\right.$ or $1 \times 10^{6}$ cells $)$. There were 5 nude mice in each group. An injection of $10^{4}$ fifth-passage H446- or H209-sphere cells generated tumor xenografts, but an equivalent number of parental cells did not have an effect (Figure 1f). In Tables 1,2, only $1 \times 10^{4}$ fifth-passage H446- or H209-sphere cells could produce 
A

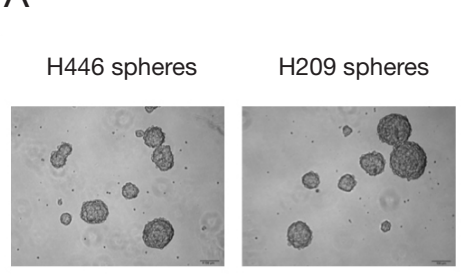

D

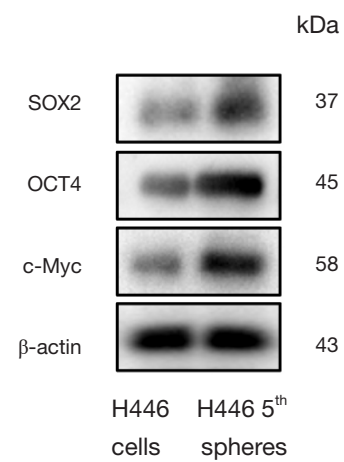

B

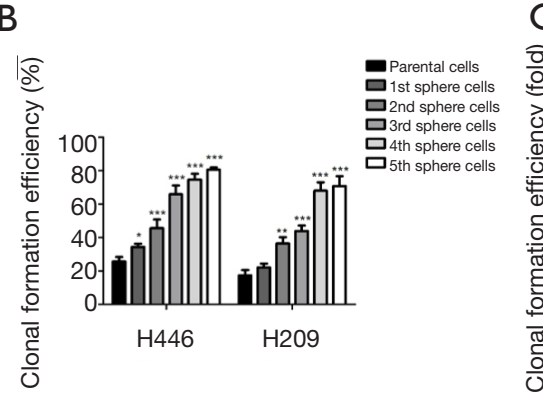

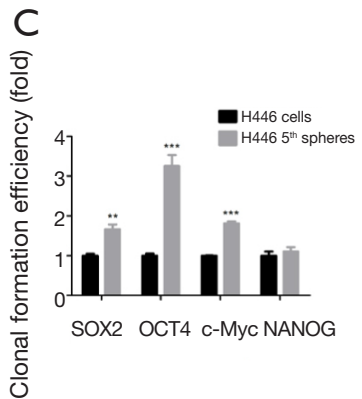

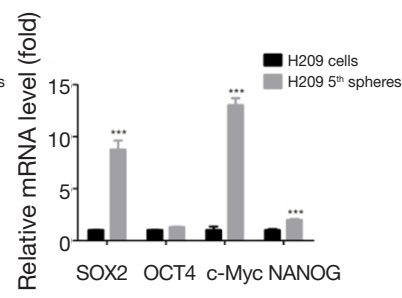

$\mathrm{kDa} \quad \mathrm{E}$
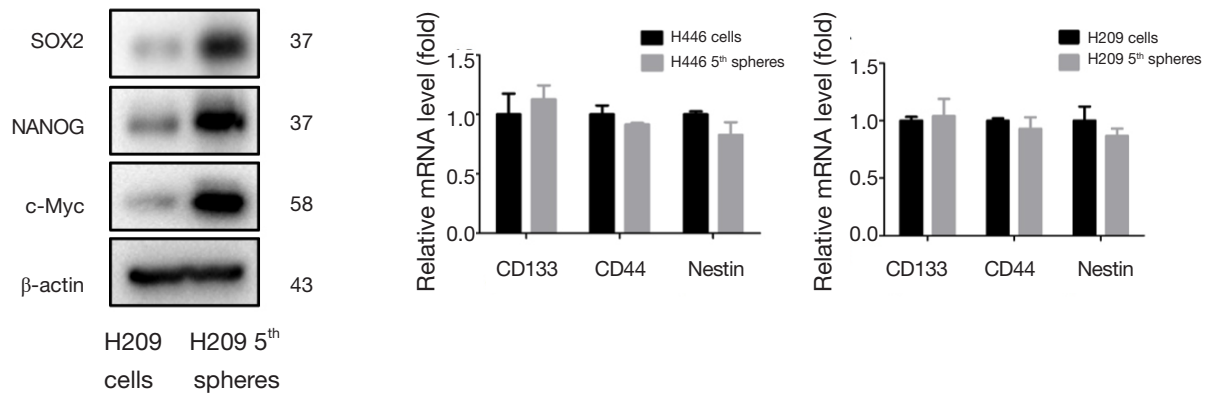

CD44

G

H446 cells

H209 cells

$\mathrm{F}$
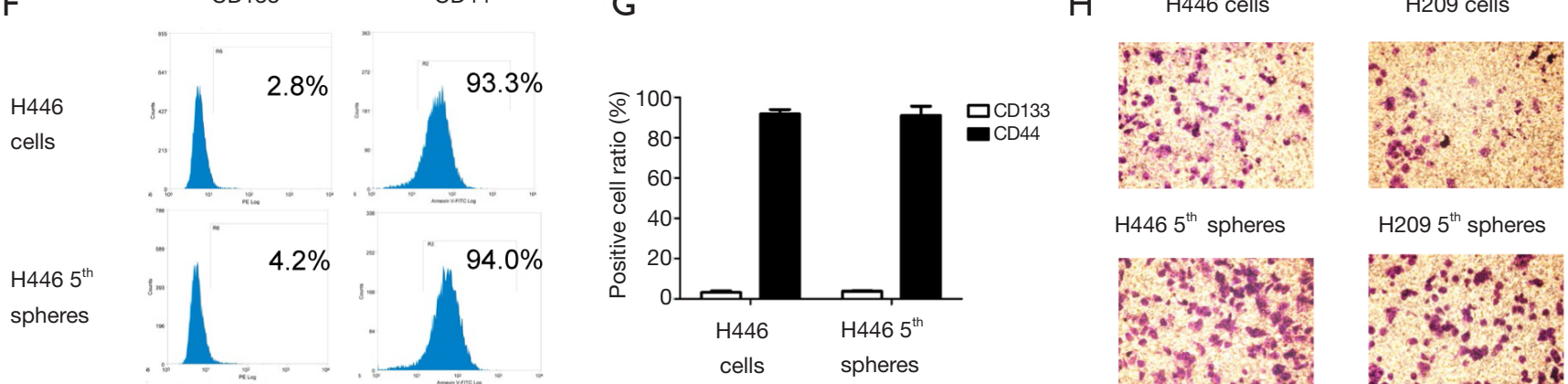

H446 $5^{\text {th }}$ spheres

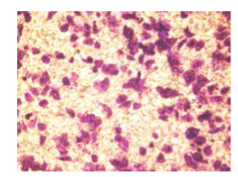

H209 $5^{\text {th }}$ spheres
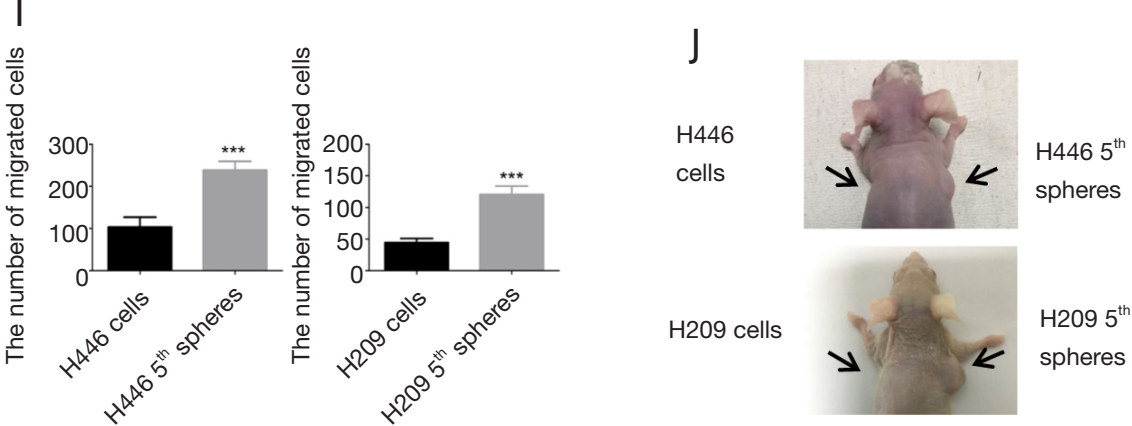

$\mathrm{K}$

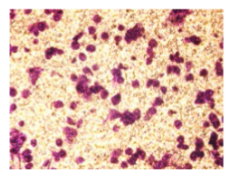

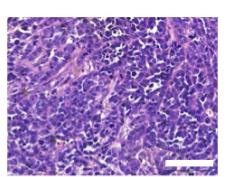

$\mathrm{H} 4465^{\text {th }}$

spheres

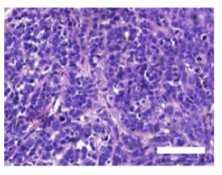

$\mathrm{H} 2095^{\text {th }}$

spheres

Figure 1 Sphere cells derived from the H446 and H209 cell lines display CSCs characteristics. (A) Microscopic images of spheres in specified serum-free conditions; Scale bar, $200 \mu \mathrm{m}$. (B) The CFE of SCLC sphere cells from the first to fifth passage and their parental cells. Expression of SOX2, OCT4, c-Myc, and NANOG (C,D), mRNA levels of CD133, CD44 and Nestin (E), ratio of CD133 ${ }^{+}$or CD44 cells $(\mathrm{F}, \mathrm{G})$ and Transwell assay (H,I) in fifth-passage SCLC sphere cells and their parental cells; the histogram shows the number of migrated cells per field; Scale bar, $50 \mu \mathrm{m}$. (J) Representative pictures showing the tumorigenic capacity of $10^{4}$ fifth-passage SCLC sphere cells and $10^{4}$ parental cells. (K) Hematoxylin and eosin (HE) staining performed on tumor xenografts from fifth-passage SCLC sphere cells; Scale bar, 50 $\mu \mathrm{m} .{ }^{*}, \mathrm{P}<0.05 ;{ }^{* *}, \mathrm{P}<0.01$ and ${ }^{* * *}, \mathrm{P}<0.001$ vs. parental cells. $\mathrm{CFE}$, clonal formation efficiency. 
Table 1 Tumor formation of H446 fifth-passage sphere cells and parental cells

\begin{tabular}{lccc}
\hline Cell types & $10^{4}$ cells & $10^{5}$ cells & $10^{6}$ cells \\
\hline H446 $5^{\text {th }}$ sphere cells & $2 / 5$ & $5 / 5$ & $5 / 5$ \\
H446 parental cells & $0 / 5$ & $0 / 5$ & $3 / 5$ \\
\hline
\end{tabular}

Equal numbers $\left(10^{4}, 10^{5}\right.$ and $\left.10^{6}\right)$ of $\mathrm{H} 446$ fifth-passage sphere cells and their parental cells were simultaneously implanted in the right and left flanks of nude mice respectively. Tumor formation was calculated three months after cell implantation.

Table 2 Tumor formation of H209 fifth-passage sphere cells and parental cells

\begin{tabular}{lccc}
\hline Cell types & $10^{4}$ cells & $10^{5}$ cells & $10^{6}$ cells \\
\hline H209 $5^{\text {th }}$ sphere & $1 / 5$ & $3 / 5$ & $5 / 5$ \\
H209 cells & $0 / 5$ & $0 / 5$ & $2 / 5$ \\
\hline
\end{tabular}

Equal numbers $\left(10^{4}, 10^{5}\right.$ and $\left.10^{6}\right)$ of $\mathrm{H} 209$ fifth-passage sphere cells and their parental cells were simultaneously implanted in the right and left flanks of nude mice respectively. Tumor formation was calculated three months after cell implantation.

xenograft tumors. On the other hand, at least $1 \times 10^{6}$ parental cells were required to develop tumors. Therefore, sphere cells were more tumorigenic than their parental cells. HE staining showed that xenografts derived from H446- and H209-sphere cells had the same histological characteristics as typical SCLCs (Figure $1 \mathrm{~K}$ ). These data indicated that the fifth-passage sphere cells derived from H446 and H209 cell lines display CSC characteristics. Therefore, the fifthpassage sphere cells were referred to as CSCs throughout the study.

\section{$\mathrm{As}_{2} \mathrm{O}_{3}$ inhibits the growth and clonogenicity of SCLC- derived CSCs}

As shown in Figure $2 \mathrm{~A}, \mathrm{As}_{2} \mathrm{O}_{3}$ inhibited the proliferation of SCLC-derived CSCs in concentration- and timedependent manners. We plotted a dose-response curve, showing that the IC50 of H446 CSCs and H209 CSCs treated with $\mathrm{As}_{2} \mathrm{O}_{3}$ for 72 hours was 1.037 and 3.272 $\mu \mathrm{M}$, respectively (Figure $2 B$ ). Consistently, treatment of SCLC-derived CSCs with $\mathrm{As}_{2} \mathrm{O}_{3}(1-4 \mu \mathrm{M})$ for five days significantly decreased the number and size of spheres (Figure 2C,D). To determine if the effect of $\mathrm{As}_{2} \mathrm{O}_{3}$ on sphere formation is reversible, $\mathrm{H}_{446}$ CSCs and $\mathrm{H} 209$ CSCs were pretreated with $\mathrm{As}_{2} \mathrm{O}_{3}$ for 72 hours before dissociating into single cells and cultured in serum-free medium for 5 days without $\mathrm{As}_{2} \mathrm{O}_{3} \cdot \mathrm{As}_{2} \mathrm{O}_{3}$ pretreatment significantly inhibited sphere growth (Figure 2C,D). The size of spheres in the $\mathrm{As}_{2} \mathrm{O}_{3}$-pretreated groups was also smaller than the control group. Besides, $\mathrm{As}_{2} \mathrm{O}_{3}$ dramatically inhibited SCLC-derived CSCs to form clonogenicity in soft agar in a dose-dependent manner (Figure 2E,F).

\section{$\mathrm{As}_{2} \mathrm{O}_{3}$ promoted cell apoptosis and reduced $\mathrm{SOX} 2$ and $c-\mathrm{Myc}$ protein expression in SCLC-derived CSCs}

We investigated the effects of $\mathrm{As}_{2} \mathrm{O}_{3}$ on CSC apoptosis. As shown in Figure $3 A, B, \mathrm{As}_{2} \mathrm{O}_{3}$ induced cell apoptosis of H446 CSCs and H209 CSCs in a dose-dependent manner. We also detected the apoptotic marker cleaved PARP. We found that its level increased in response to $\mathrm{As}_{2} \mathrm{O}_{3}$ treatment (Figure $3 C$ ). The impact of $\mathrm{As}_{2} \mathrm{O}_{3}$ on the cell cycle was also examined. Our data demonstrated that $\mathrm{As}_{2} \mathrm{O}_{3}$ treatment had no significant effect on the cell cycle in both H446 CSCs and H209 CSCs (Figure 3D,E). SOX2 and c-Myc are two key stem cell transcription factors required for self-renewal and tumorigenicity of CSCs. Our data showed that $\mathrm{As}_{2} \mathrm{O}_{3}$ treatment triggered an immediate downregulation of SOX2 and c-Myc mRNA and protein levels in H446 CSCs and H209 CSCs (Figure 3F,G). This downregulation effect was dependent on $\mathrm{As}_{2} \mathrm{O}_{3}$ concentration

\section{SOX2 silencing suppressed SCLC-derived CSCs growth and induced apoptosis}

SOX2 Silencing has been shown to decrease selfrenewal and abrogate tumorigenicity in glioblastoma CSCs (26) and melanoma CSCs (27). To clarify its function in SCLC-derived CSCs, H446 CSCs and H209 CSCs were infected with SOX2 shRNA lentiviruses (shSOX2-1 and shSOX2-2) and control lentiviruses (shNT). Green fluorescence expression could be observed under a fluorescence microscope 72 hours after infection (Figure 4A). shSOX2-1 and shSOX2-2 reduced the SOX2 mRNA level by $64-80 \%$ compared to shNT in H446 CSCs and H209 CSCs (Figure 4B). We used western blotting to verify that SOX2 protein expression in the shSOX2-1 and shSOX2-2 groups was lower than that in the shNT group (Figure 4C). As shown in Figure 4D, SOX2 knockdown significantly decreased sphere size. In addition, SOX2 knockdown drastically reduced the number of spheres (Figure 4E). SOX2 silencing also dramatically inhibited H446 CSC and H209 CSC clonogenicity formation in soft agar (Figure $4 F$ ). SOX2 

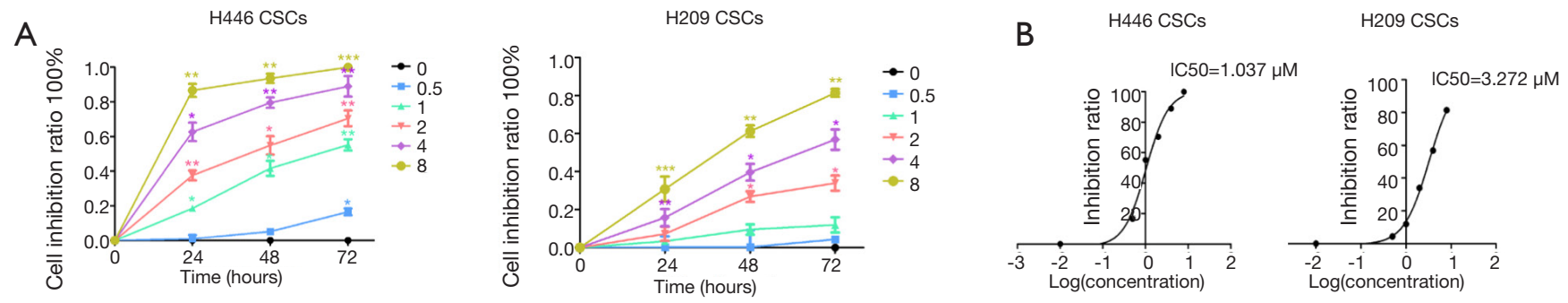

C
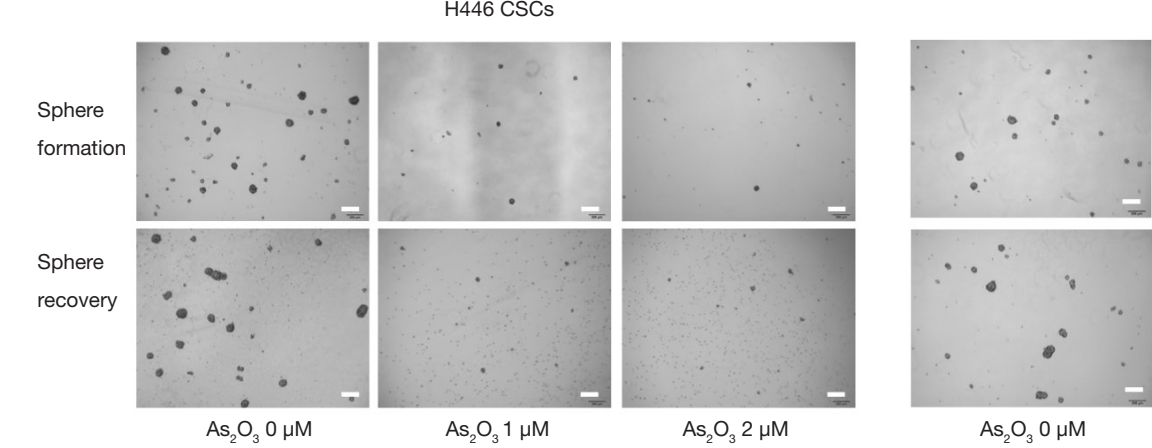

H209 CSCs

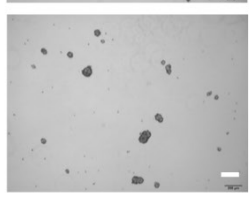

$\mathrm{As}_{2} \mathrm{O}_{3} 0 \mu \mathrm{M}$

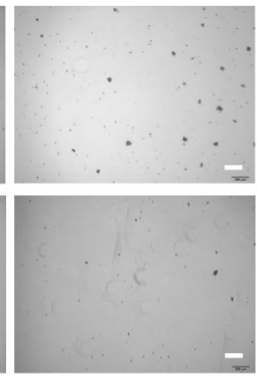

$\mathrm{As}_{2} \mathrm{O}_{3} 2 \mu \mathrm{M}$
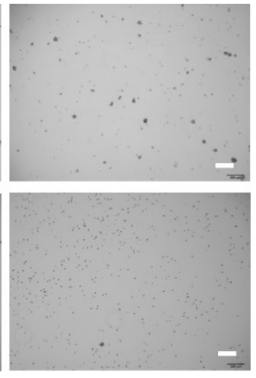

$\mathrm{As}_{2} \mathrm{O}_{3} 4 \mu \mathrm{M}$
D

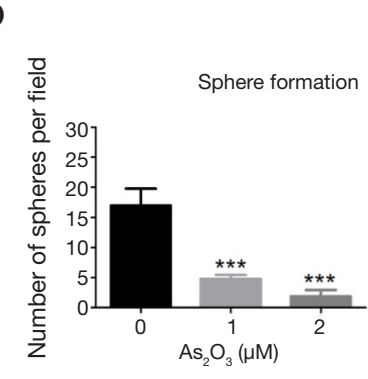

E

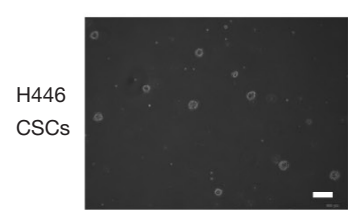

$\mathrm{As}_{2} \mathrm{O}_{3} 0 \mu \mathrm{M}$

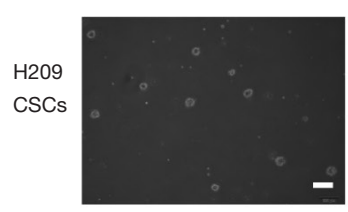

$\mathrm{As}_{2} \mathrm{O}_{3} \mathrm{O} \mu \mathrm{M}$
H446 CSCs

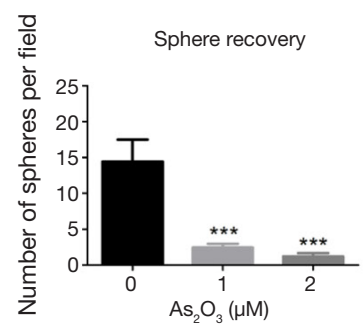

Soft agar clonal assay

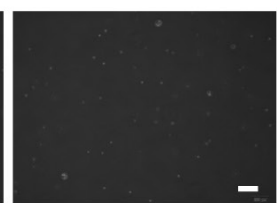

$\mathrm{As}_{2} \mathrm{O}_{3} 1 \mu \mathrm{M}$

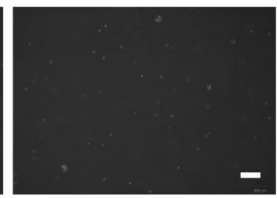

$\mathrm{As}_{2} \mathrm{O}_{3} 2 \mu \mathrm{M}$
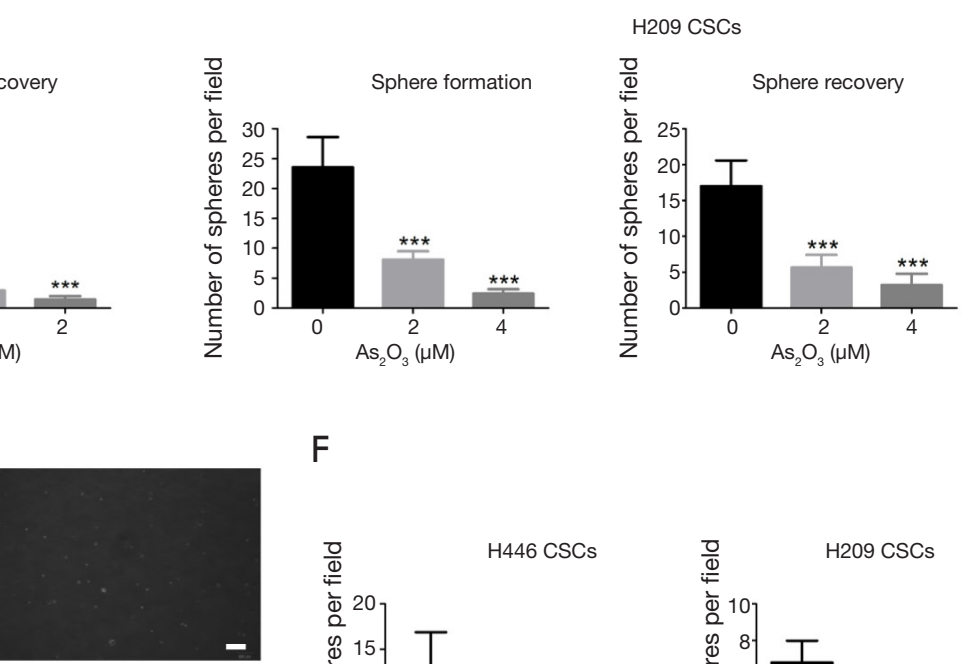

$\mathrm{As}_{2} \mathrm{O}_{3} 2 \mu \mathrm{M}$

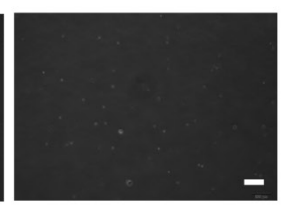

$\mathrm{As}_{2} \mathrm{O}_{3} 4 \mu \mathrm{M}$
F
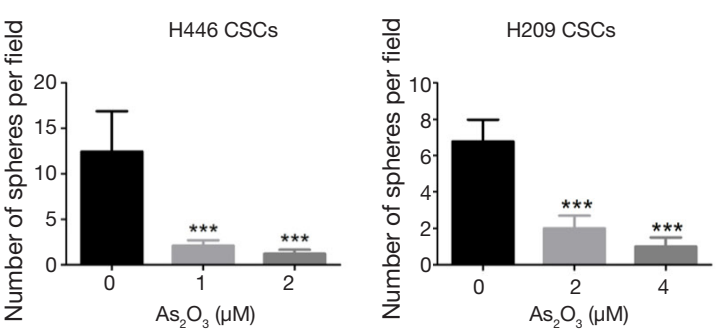

Figure $2 \mathrm{As}_{2} \mathrm{O}_{3}$ inhibits the growth and clonogenicity of SCLC-derived CSCs. H446 CSCs and H209 CSCs were treated with control or $\mathrm{As}_{2} \mathrm{O}_{3}$. (A) CCK8 assay. (B) Dose response curve of H446 CSCs and H209 CSCs treated with As $\mathrm{O}_{3}$ for 72 hours. (C) Representative morphology after $\mathrm{As}_{2} \mathrm{O}_{3}$ treatment (sphere formation assay) or pretreatment (sphere recovery assay); Scale bar, $200 \mu \mathrm{m}$. (D) Statistical bar graphs of sphere number. (E) Representative images of colony formation; Scale bar, $200 \mu \mathrm{m}$. (F) Statistical bar graphs of colony number. *, $\mathrm{P}<0.05$, ${ }^{* *}, \mathrm{P}<0.01$ and ${ }^{* * *}, \mathrm{P}<0.001$ vs. the control group. CFE, clonal formation efficiency. 
A
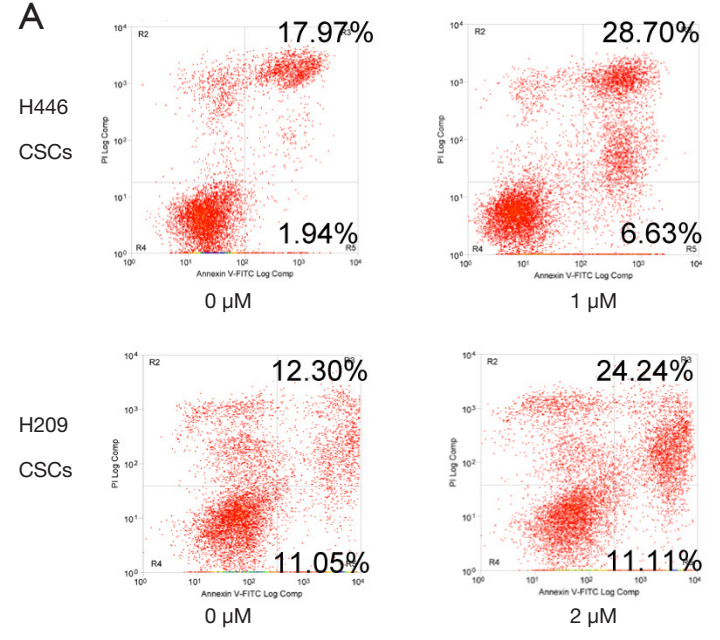

C
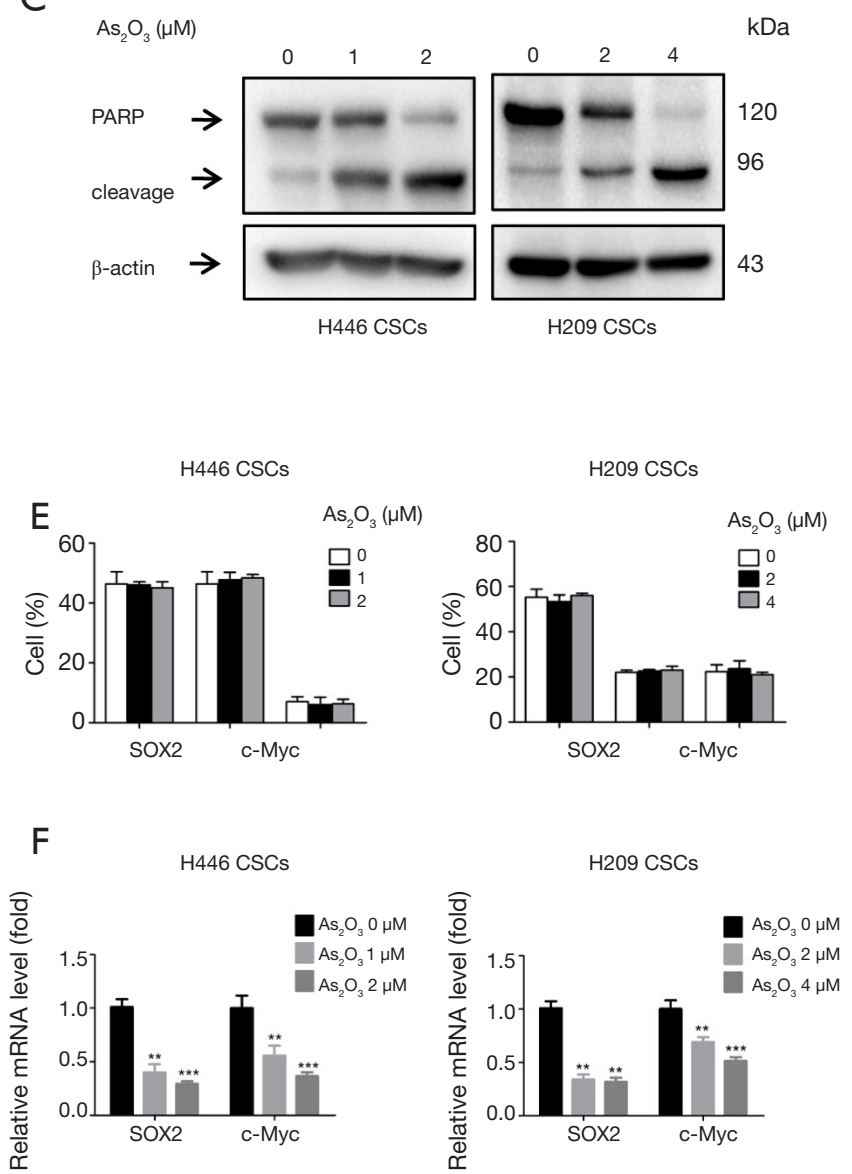

B
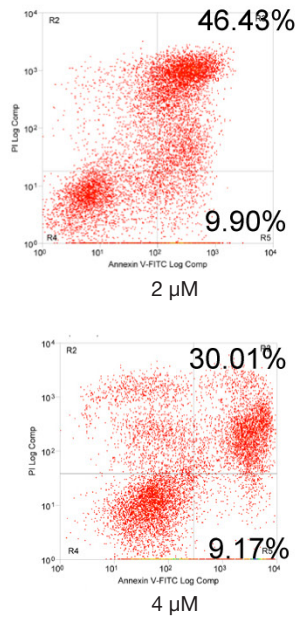

H446 CSCs
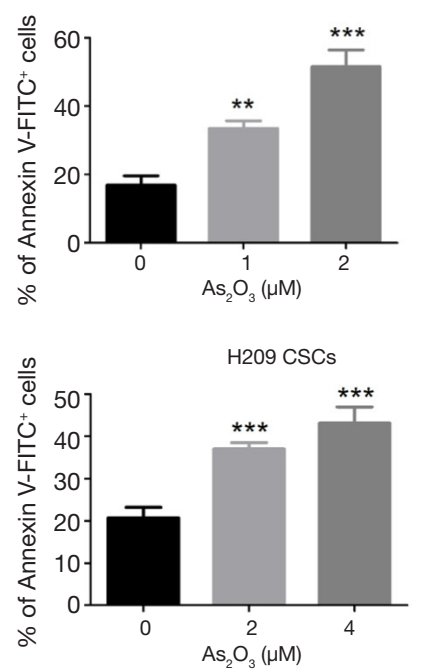

Figure $3 \mathrm{As}_{2} \mathrm{O}_{3}$ promoted apoptosis and reduced SOX2 and c-Myc protein in SCLC-derived CSCs. H446- and H209-CSCs were treated with control or $\mathrm{As}_{2} \mathrm{O}_{3}$. (A) Flow cytometry analysis of early and late apoptotic rates. (B) Statistical bar graphs of total apoptotic rates. (C) Western blot analysis of cleaved PARP. (D) Cell cycle analysis. (E) Histogram graphs of G0/G1, S and G2/M phase cell proportions. qPCR (F) and Western blot analysis (G) of SOX2 and c-Myc expression in control and $\mathrm{As}_{2} \mathrm{O}_{3}$ groups. ${ }^{* *}, \mathrm{P}<0.01$ and ${ }^{* * *}, \mathrm{P}<0.001$ vs. the control group. 
A
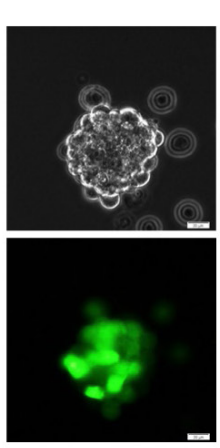

shNT
H446 CSCs
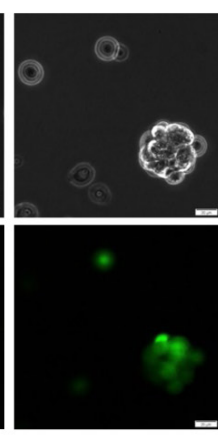

shSOX2- 1

B

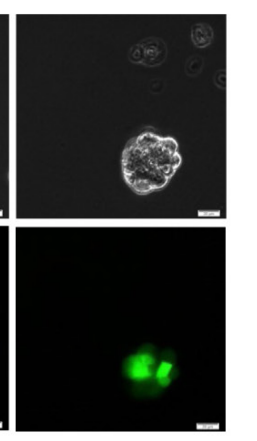

shSOX2-2
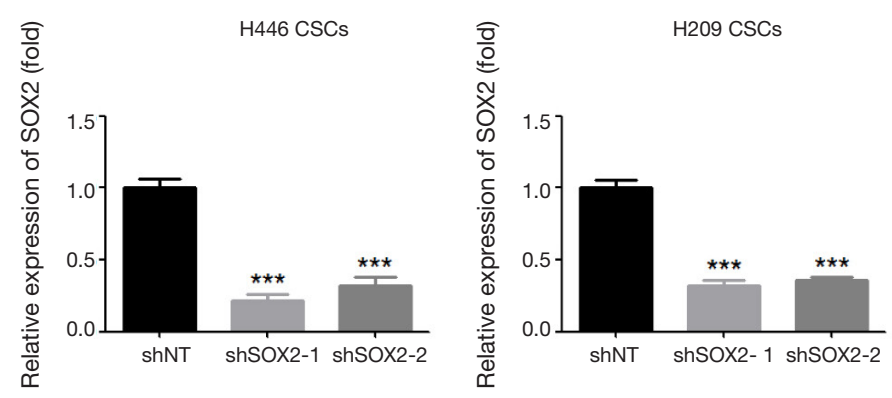

C

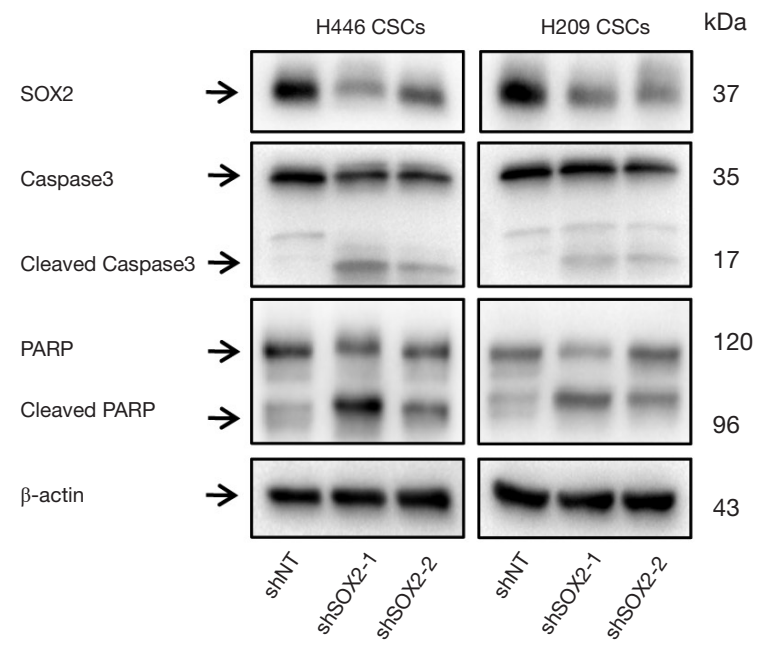

E
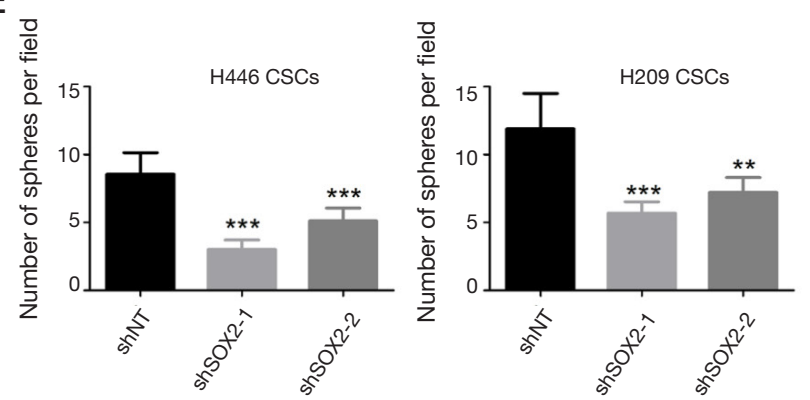

$\mathrm{F}$
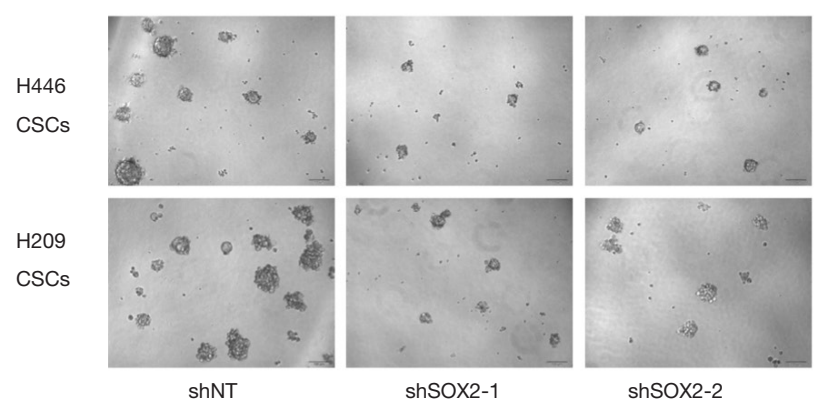

shsox2-2
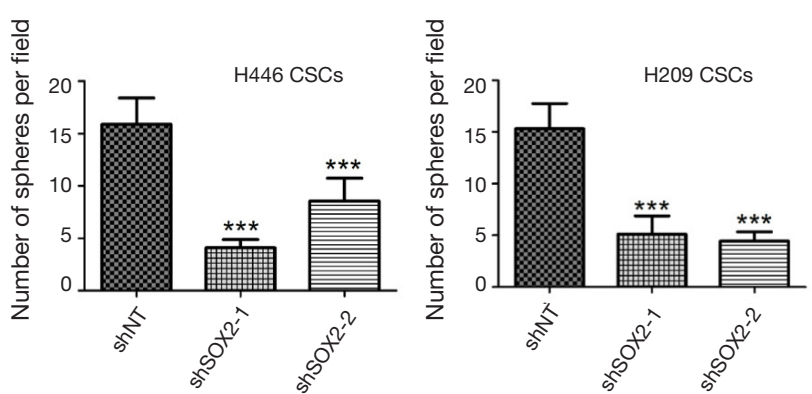

Figure 4 SOX2 silencing suppressed SCLC-derived CSCs growth and induced apoptosis. H446 CSCs and H209 CSCs were infected with shNT, shSOX2-1, or shSOX2-2 lentiviruses. (A) The morphology (upper panels) and green fluorescent expression (lower panels) of H446 CSCs infected with lentiviruses for 72 hours; Scale bar, $50 \mu \mathrm{m}$. (B) qPCR of SOX2. (C) Western blot analysis of SOX2, cleaved caspase-3, and cleaved PARP. (D) Representative micrographs of sphere formation; Scale bar, $100 \mu \mathrm{m}$. (E) Statistical bar graphs of sphere number. (F) Statistical bar graphs of colony number. ${ }^{* *}, \mathrm{P}<0.01$ and ${ }^{* * *}, \mathrm{P}<0.001$ vs. shNT. 
silencing induced cleaved caspase- 3 and cleaved PARP expression (Figure 4C).

\section{Anti-cancer efficacy of $\mathrm{As}_{2} \mathrm{O}_{3}$ against xenografts derived from SCLC-derived CSCs}

We further investigated the efficiency of $\mathrm{As}_{2} \mathrm{O}_{3}$ against tumor growth of SCLC-derived CSCs in vivo. The nude mice were subcutaneously inoculated in the right flanks with SCLC-derived CSCs $\left(1 \times 10^{6}\right.$ cells per mouse). The tumor-bearing mice were randomly divided into control (NS) group, 2.5 or $5.0 \mathrm{mg} / \mathrm{kg} \mathrm{As}_{2} \mathrm{O}_{3}$ group when the average tumor volume reached $60-70 \mathrm{~mm}^{3}$. There were 7 mice in each group. The average tumor volumes of the 2.5 and $5.0 \mathrm{mg} / \mathrm{kg} \mathrm{As}_{2} \mathrm{O}_{3}$ groups were significantly smaller than the control group from day 6 to 14 in $\mathrm{H} 446$ CSCs tumor-bearing mice (Figure $5 A, B$ ). A similar inhibitory effect of $\mathrm{As}_{2} \mathrm{O}_{3}$ on tumor growth was seen in H209 CSCs xenograft models, and the average tumor volumes of the 2.5 and $5.0 \mathrm{mg} / \mathrm{kg} \mathrm{As} \mathrm{O}_{2} \mathrm{O}_{3}$ groups were significantly smaller than the control group from day 8 to 14 (Figure $5 A, B$ ). By a repeated measure ANOVA, we found that either time or intervention significantly affected tumor volume in H446 CSCs and H209 CSCs xenograft models. There is an interaction between time and intervention. On day 14, the mean tumor weight of the $\mathrm{As}_{2} \mathrm{O}_{3}$-treated groups was significantly lower than the control group (Figure 5C). TUNEL staining showed that treatment with 2.5 and $5.0 \mathrm{mg} / \mathrm{kg} \mathrm{As}_{2} \mathrm{O}_{3}$ increased the apoptotic cell ratio in xenograft models (Figure 5D). These data indicated that $\mathrm{As}_{2} \mathrm{O}_{3}$ treatment significantly suppressed tumor growth and induced apoptosis in SCLC CSCs-derived xenografts. Besides, immunofluorescent staining demonstrated that $\mathrm{As}_{2} \mathrm{O}_{3}$ treatment dramatically reduced $\mathrm{SOX}^{+}$cell and $\mathrm{c}-\mathrm{Myc}^{+}$cell population in xenografts (Figure $5 E, F)$. Importantly, no obvious side effects were observed during $\mathrm{As}_{2} \mathrm{O}_{3}$ treatment. Collectively, $\mathrm{As}_{2} \mathrm{O}_{3}$ treatment resulted in the reduction of SCLC-derived CSCs in vivo at non-toxic doses.

\section{Hedgehog pathway was activated in SCLC-derived CSCs and $\mathrm{As}_{2} \mathrm{O}_{3}$ down-regulated GLI1 and its downstream genes}

The Hedgehog signaling pathway plays a key role in the regulation of proliferation, differentiation, and tumorigenic potential of CSCs. GLI1 is the key transcription factor of Hedgehog signaling, and it induces the transcription of numerous target genes like PTCH1 and n-Myc. As shown in Figure $6 A$, the mRNA levels of GLI1, PTCH1 and n-Myc were significantly up-regulated in H446 CSCs and H209 CSCs compared to their parental cells. Nest, we analyzed the effects of $\mathrm{As}_{2} \mathrm{O}_{3}$ on the expression of GLI1, PTCH1 and $\mathrm{n}-\mathrm{Myc}$ in SCLC-derived CSCs in vitro and in vivo. We found that $\mathrm{As}_{2} \mathrm{O}_{3}$ treatment remarkably downregulated the expression of GLI1 protein and its target genes PTCH1 and $\mathrm{n}-\mathrm{Myc}$ in $\mathrm{H} 446 \mathrm{CSCs}$ and $\mathrm{H} 209$ CSCs in vitro (Figure $6 B, C)$. As expected, $\mathrm{As}_{2} \mathrm{O}_{3}$ administration also induced the downregulation of GLI1 protein and its downstream genes PTCH1 and n-Myc in H446 CSC- and H209 CSC-derived xenografts (Figure 6D,E).

\section{GLI inbibitor recapitulated and enhanced therapeutic effects of $\mathrm{As}_{2} \mathrm{O}_{3}$ in SCLC-derived CSCs}

To further verify the possible involvement of Hedgehog pathways in the stemness phenotype and apoptotic induction in $\mathrm{As}_{2} \mathrm{O}_{3}$-treated SCLC-derived CSCs, GANT61, a GLI transcription factor inhibitor, was applied. H446 CSCs and $\mathrm{H} 209$ CSCs were treated with vehicle (control), $\mathrm{As}_{2} \mathrm{O}_{3}$ alone, GANT-61 alone, or a combination of $\mathrm{As}_{2} \mathrm{O}_{3}$ and GANT-61. We found that GANT-61 down-regulated the expression of GLI1 protein and increased the inhibitory effect of $\mathrm{As}_{2} \mathrm{O}_{3}$ on GLI1 protein (Figure 7A). The sphere formation assay showed that $1 \mu \mathrm{M} \mathrm{As} \mathrm{O}_{3}$ or $5 \mu \mathrm{M}$ GANT61 decreased sphere formation compared to control (Figure $7 B, C)$. Strikingly, sphere formation was almost eliminated by the combined treatment (Figure 7B,C). As measured by flow cytometer, the apoptosis percentage in the $\mathrm{As}_{2} \mathrm{O}_{3}$, GANT-61 or $\mathrm{As}_{2} \mathrm{O}_{3}+$ GANT-61 groups were significantly higher than in control group (Figure 7D,E). Besides, a significant increase in apoptosis was found in the combined group compared to the $\mathrm{As}_{2} \mathrm{O}_{3}$ alone group (Figure 7D,E). Furthermore, $\mathrm{As}_{2} \mathrm{O}_{3}$, GANT-61 or $\mathrm{As}_{2} \mathrm{O}_{3}+$ GANT-61 increased the expression of cleaved PARP and decreased SOX2 and c-Myc expression, compared to the control (Figure $7 F$ ). The effects of the combined group were more significant than the $\mathrm{As}_{2} \mathrm{O}_{3}$ alone group.

\section{Discussion}

The high recurrence rate in patients with SCLC highlights the urgent need for therapeutic drugs against CSCs that are critical for therapeutic resistance, tumor metastasis and recurrence $(28,29)$. The sphere culture system was initially developed for in vitro expansion of normal neural stem cells (30), and it has been widely used recently to 
A

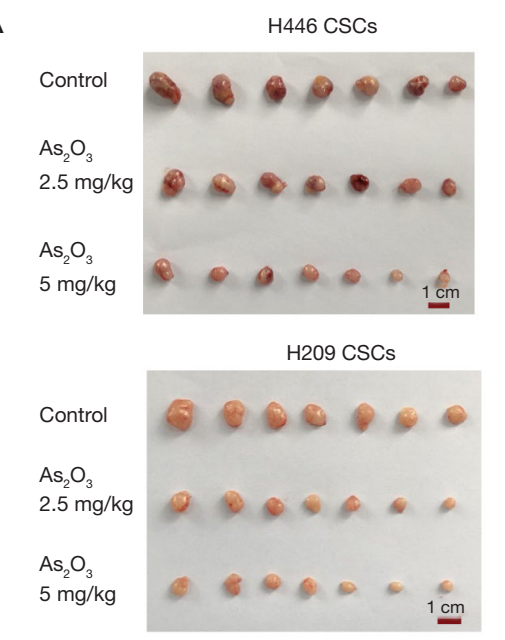

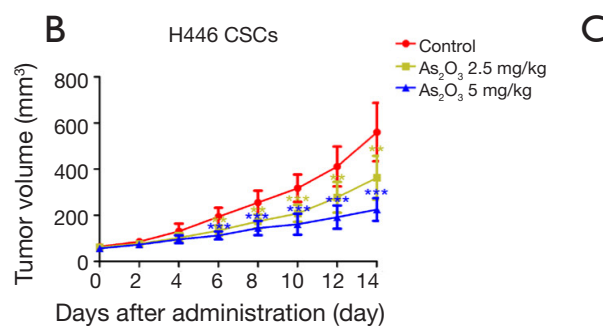

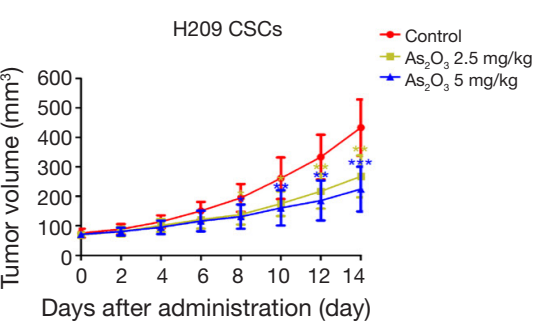

C
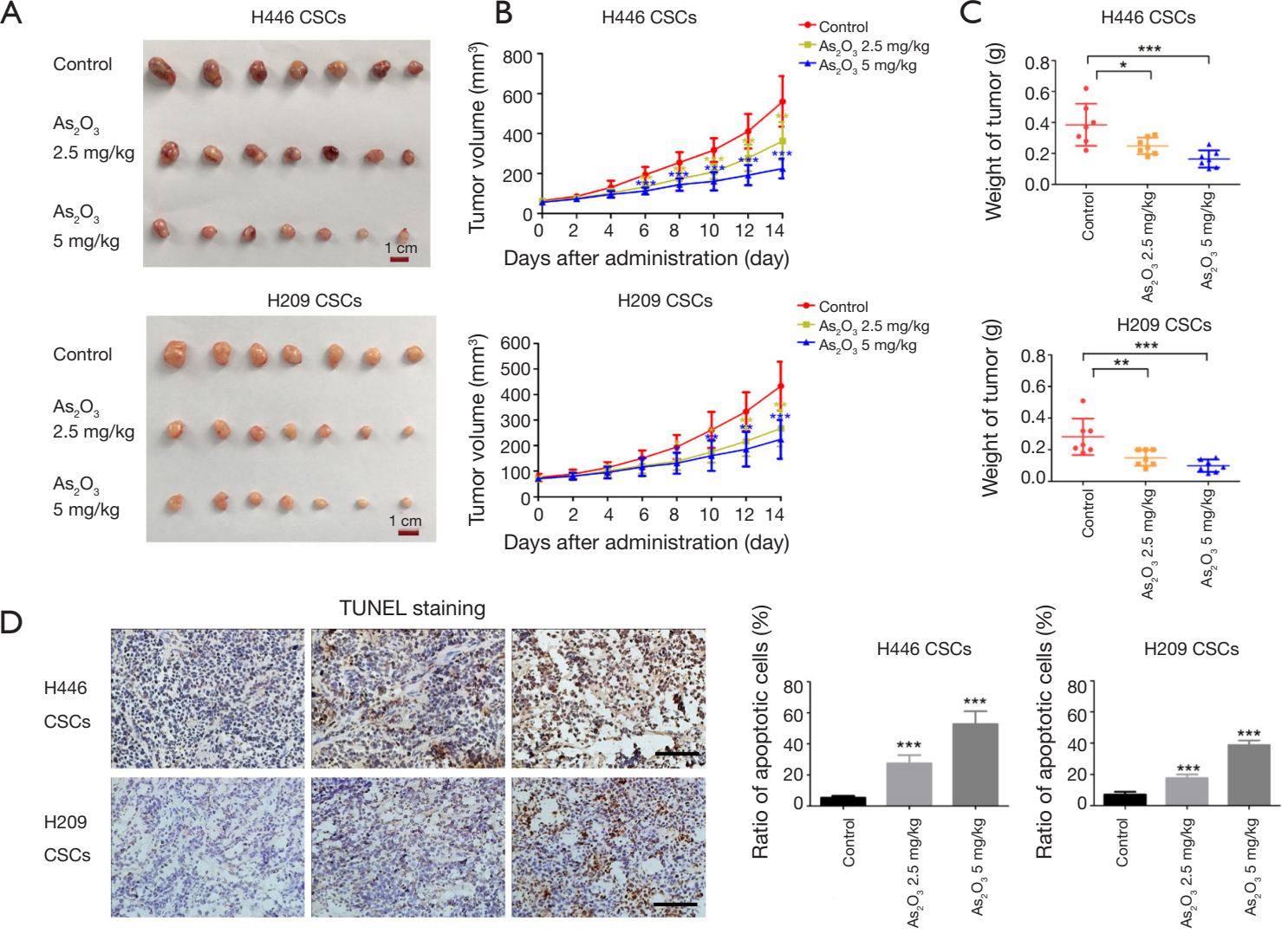

E
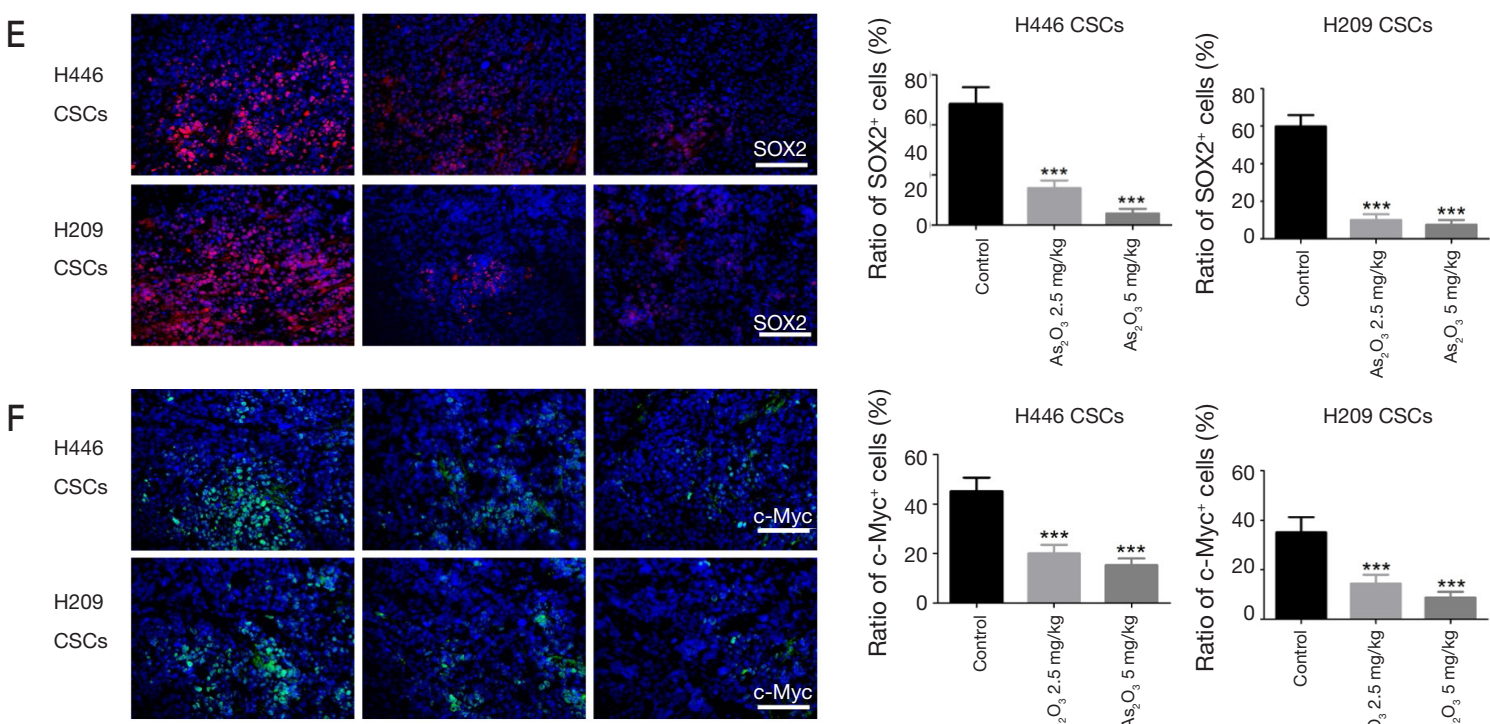

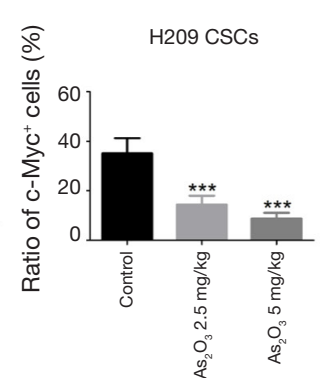

Figure 5 Anti-cancer efficacy of $\mathrm{As}_{2} \mathrm{O}_{3}$ against xenografts derived from SCLC-derived CSCs. (A) Tumors derived from $\mathrm{H} 446$ CSCs or H209 CSCbearing nude mice after 14 days of $\mathrm{As}_{2} \mathrm{O}_{3}$ treatment; Scale bar, $1 \mathrm{~cm}$. (B) The growth curves of tumor volume of $\mathrm{H} 446 \mathrm{CSCs}$ or H209 CSC-bearing mice. (C) Scatter diagrams of tumor weight of $\mathrm{H} 446 \mathrm{CSCs}$ or $\mathrm{H} 209$ CSC-bearing mice in control, $2.5 \mathrm{mg} / \mathrm{kg}$ and, $5.0 \mathrm{mg} / \mathrm{kg} \mathrm{As} \mathrm{O}_{3}$ group. (D) TUNEL staining on tumor sections from $\mathrm{H} 446$ CSCs or H209 CSC-bearing mice treated with control, $2.5 \mathrm{mg} / \mathrm{kg}$, or $5.0 \mathrm{mg} / \mathrm{kg} \mathrm{As} \mathrm{O}_{3}$; Nuclei were counterstained with hematoxylin; Scale bar, $50 \mu \mathrm{m}$; Statistical bar graphs of apoptotic cell ratio in tumors. (E,F) Immunofluorescent staining of SOX2 (in red) or c-Myc (in green) on tumor sections from H446 CSCs or H209 CSC-bearing mice treated with control, $2.5 \mathrm{mg} / \mathrm{kg}$, or $5.0 \mathrm{mg} / \mathrm{kg}$ $\mathrm{As}_{2} \mathrm{O}_{3}$; Nuclei were counterstained with DAPI (in blue); Scale bar, $50 \mu \mathrm{m}$; Statistical bar graphs showing percentage of SOX2 ${ }^{+}$or c-Myc ${ }^{+}$cells in tumors. ${ }^{*}, \mathrm{P}<0.05,{ }^{* *}, \mathrm{P}<0.01$ and $^{* * *}, \mathrm{P}<0.001$ vs. the control (NS) group. NS, normal saline. 



Figure 6 Hedgehog pathway was activated in SCLC-derived CSCs and $\mathrm{As}_{2} \mathrm{O}_{3}$ down-regulated GLI1 and its downstream genes. (A) qPCR of GLI1, PTCH1, and n-Myc in SCLC-derived CSCs and their parental cells. (B) Western blot analysis of GLI1 protein in H446 CSCs and $\mathrm{H} 209$ CSCs treated with $\mathrm{As}_{2} \mathrm{O}_{3}$ for 48 hours. (C) qPCR of PTCH1 and n-Myc in $\mathrm{H}_{446} \mathrm{CSCs}$ and $\mathrm{H}_{209} \mathrm{CSCs}$ treated with As $\mathrm{O}_{3}$ for 48 hours. (D) Western blot analysis of GLI1 protein in H446 CSCs or H209 CSC-bearing mice treated with control, $2.5 \mathrm{mg} / \mathrm{kg}$, or $5.0 \mathrm{mg} / \mathrm{kg} \mathrm{As} \mathrm{O}_{3}$ for 14 days. (E) qPCR of PTCH1 and n-Myc in H446 CSCs or H209 CSC-bearing mice treated with control, $2.5 \mathrm{mg} / \mathrm{kg}$, or $5.0 \mathrm{mg} / \mathrm{kg} \mathrm{As}_{2} \mathrm{O}_{3}$ for 14 days. * $\mathrm{P}<0.05$, **, $\mathrm{P}<0.01$ and ***, $\mathrm{P}<0.001$ vs. control.

isolate and characterize CSCs from different tumors including SCLC $(6,7)$. When cultured in serum-free medium containing EGF and bFGF and low adherence substrate, undifferentiated cells grow slowly and form floating colonies called tumor spheres while differentiated cells die (31). Tumor sphere cells exhibit powerful selfrenewal capacity, tumor-initiating abilities, and they are more resistant to chemotherapy and radiotherapy $(23,24)$. Since there is no specific surface marker for SCLC stem cells, the sphere culture method was used to enrich CSCs in the SCLC cell lines H446 and H209. We found that sphere cells possessed potent self-renewal capacity. They could be passaged serially more than 30 times when dissociated into single cells. The CFE increased from the first to the fifthpassage sphere cells, and more than $70 \%$ of the fifth-passage sphere cells could regenerate colonies. OCT4, SOX2, NANOG and c-Myc are master transcription factors that maintain the self-renewal and pluripotency of embryonic stem cells (ESCs) (32), and they are also essential for CSC function (33). We also observed higher expression levels of SOX2, OCT4, c-Myc, and NANOG in the fifth-passage H446 spheres or H209 spheres than in their parental cells. 

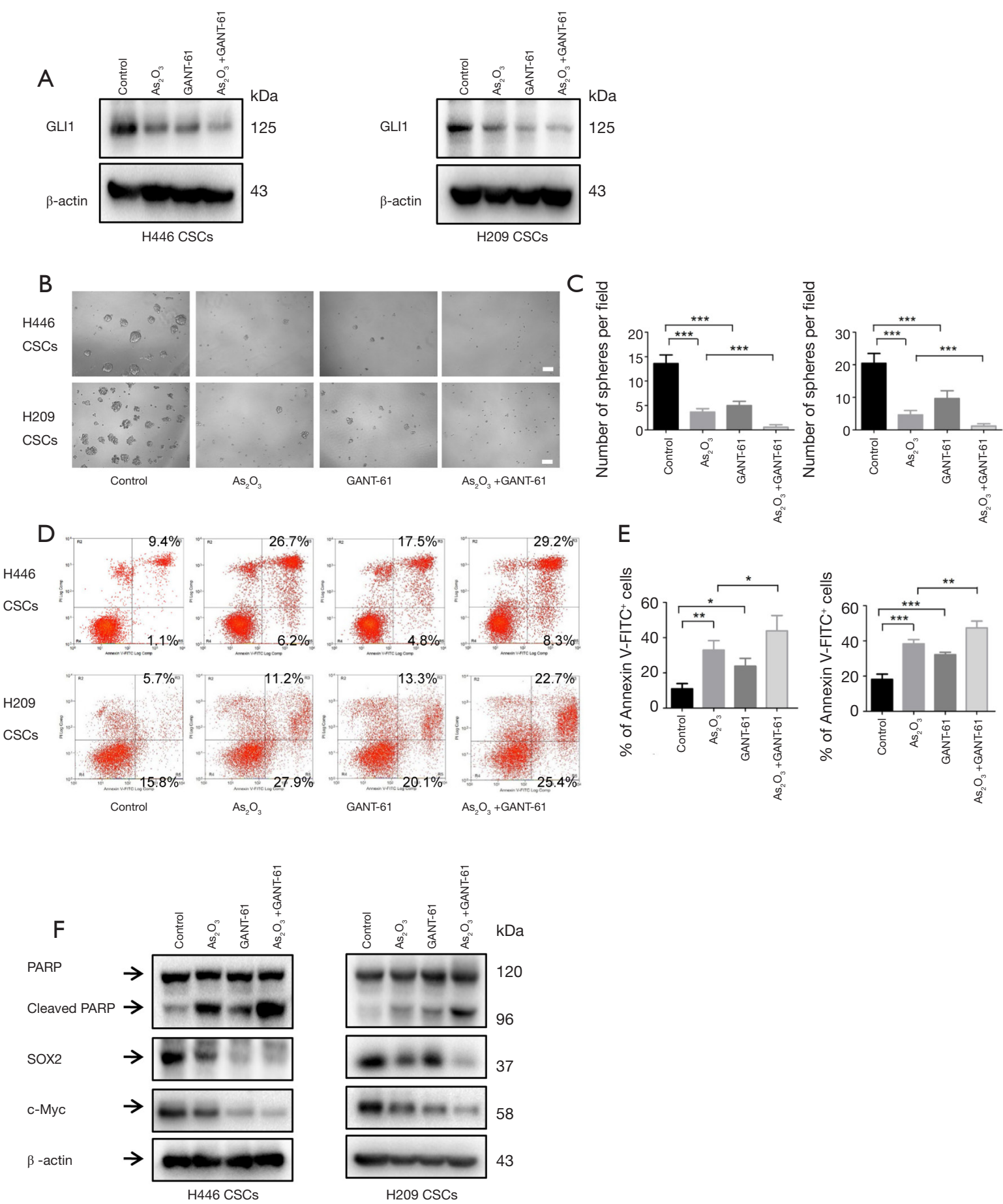

Figure 7 GLI inhibitor recapitulated and enhanced the therapeutic effects of $\mathrm{As}_{2} \mathrm{O}_{3}$ in SCLC-derived CSCs. $\mathrm{H} 446$ CSCs were treated with control, $1 \mu \mathrm{M} \mathrm{As}_{2} \mathrm{O}_{3}, 5 \mu \mathrm{M}$ GANT-61, or $1 \mu \mathrm{M} \mathrm{As}_{2} \mathrm{O}_{3}+5 \mu \mathrm{M}$ GANT-61, respectively. H209 CSCs were treated with control, $2 \mu \mathrm{M} \mathrm{As}_{2} \mathrm{O}_{3}, 5 \mu \mathrm{M}$ GANT-61, or $2 \mu \mathrm{M} \mathrm{As}_{2} \mathrm{O}_{3}+5 \mu \mathrm{M}$ GANT-61, respectively. (A) Western blot analysis of GLI1 protein. (B) Representative micrographs of sphere formation; Scale bar, $100 \mu \mathrm{m}$. (C) Statistical bar graphs of sphere number. (D) Flow cytometry analysis of early and late apoptotic rates. (E) Statistical bar graphs of total apoptotic rates. (F) Western blot analysis of cleaved PARP, SOX2, and c-Myc protein. * $\mathrm{P}<0.05$; **, $\mathrm{P}<0.01$ and ${ }^{* * *}, \mathrm{P}<0.001$. 
However, the expression levels of commonly used stem cell markers CD133, CD44 and Nestin did not increase in the fifth-passage spheres compared to their parental cells. These data indicate that CD133, CD44 and Nestin may not specific CSC markers and are not restricted to CSCs in SCLC. Other literatures are in favor of our findings. Meng et al. (34) concluded that CD133+ and CD133subpopulations sorted from H446 cells displayed similar abilities of self-renewal, differentiation, invasion, as well as chemotherapy resistance. Coppola et al. (35) demonstrated that CD44 expression was inversely correlated with more aggressive types in SCLC. In addition, the invasion ability of the fifth-passage sphere cells was significantly higher than their parental cells. In vivo tumorigenesis is the major characteristic of CSCs, and it is the standard method for CSC identification (25). Notably, we observed that the fifth-passage SCLC sphere cells were approximately 100fold more tumorigenic than their parental cells. Our data indicate that sphere cells derived from H446 and H209 cell lines grown under specified serum-free conditions display CSC properties.

$\mathrm{As}_{2} \mathrm{O}_{3}$ is an FDA-approved drug for APL treatment. Several studies have reported the therapeutic effects of $\mathrm{As}_{2} \mathrm{O}_{3}$ on the cell growth of gliomas $(11,12)$, breast cancer (13), hepatocellular carcinoma (14) and pancreatic cancer (15) by targeting CSCs. The cellular response of SCLC-derived CSCs to $\mathrm{As}_{2} \mathrm{O}_{3}$ must be explored. Our results revealed that $\mathrm{As}_{2} \mathrm{O}_{3}$ treatment dramatically inhibited cell viability, sphere-forming, and colony formation ability of H446- and H209-derived CSCs in a concentration-dependent manner. This indicates that $\mathrm{As}_{2} \mathrm{O}_{3}$ treatment has potent inhibitory effects on SCLC-derived CSCs growth. Sphere formation inhibition was also found after $\mathrm{As}_{2} \mathrm{O}_{3}$ withdrawal, suggesting that the inhibitory effects of $\mathrm{As}_{2} \mathrm{O}_{3}$ on SCLC-derived CSCs is persistent.

In vitro assays showed that $\mathrm{As}_{2} \mathrm{O}_{3}$ treatment strongly induced apoptosis of H446 CSCs and H209 CSCs, but showed little effect on the cell cycle. In vivo, $\mathrm{As}_{2} \mathrm{O}_{3}$ treatment suppressed the tumor growth of H446- or H209-derived CSC-bearing nude mice and increased cell apoptosis in a dose-dependent manner. These data suggest that apoptosis induction may underlie the inhibitory effects of $\mathrm{As}_{2} \mathrm{O}_{3}$ on growth of SCLC-derived CSCs. SOX2 and MYC family genes have been found to be amplified in about $20 \%$ of SCLC samples $(36,37)$. SOX2 knockdown decreased self-renewal and abrogated tumorigenicity in glioblastoma CSCs (26) and melanoma CSCs (27). c-Myc silencing in glioma CSCs increased apoptosis, reduced proliferation, and resulted in the failure to form tumors in immunodeficient mice $(38,39)$. We found that their expression levels were significantly suppressed by $\mathrm{As}_{2} \mathrm{O}_{3}$ treatment. Similarly, $\mathrm{As}_{2} \mathrm{O}_{3}$ treatment dramatically reduced the $\mathrm{SOX}_{2}^{+}$and $\mathrm{c}-\mathrm{Myc}^{+}$cell proportion in $\mathrm{H} 446 \mathrm{CSC}-$ and H209 CSC-derived xenografts. Besides, SOX2 knockdown markedly reduced clonogenicity and sphere formation and induced cell apoptosis in SCLC-derived CSCs, indicating its role in maintaining the self-renewal of SCLC-derived CSCs.

Hedgehog signaling is a highly conservative signaling pathway in cell fate determination and pattern formation during embryonic development. The Hedgehog signaling pathway is inactivated in most adult tissues, but it is aberrantly reactivated in a variety of human cancers (40). Hedgehog signaling is initiated when Hh ligands (Shh, Ihh, or Dhh) bind to PTCH receptors, diminishing its inhibitory effects on Smoothened (41). The activation of Smoothened gives rise to activation and nuclear translocation of transcription factors GLI, which subsequently activate downstream genes like GLI1, PTCH1, n-Myc, CyclinD, and FOX. GLI1 serves as a key activator and also the target gene of the Hedgehog pathway, so it can reflect pathway activity. Prior studies by our team and other groups showed that $\mathrm{As}_{2} \mathrm{O}_{3}$ has significant antitumor or anti-CSC effects on some types of solid tumors via GLI1 inhibition $(14,15,20,41,42)$. It has been speculated that $\mathrm{As}_{2} \mathrm{O}_{3}$ might affect the normal structure of GLI protein by directly binding to the zinc finger domain of GLI protein, thereby interfering the binding of GLI to other proteins or DNA and leading to GLI degradation by the proteasome (41). However, it is still unclear whether $\mathrm{As}_{2} \mathrm{O}_{3}$ increases apoptosis and suppresses SCLC-derived CSC growth via the Hedgehog signaling pathways. Here, we found that GLI1, PTCH1 and n-Myc expression levels were upregulated in H446- or H209-derived CSCs compared to their parental cells. Next, we verified that $\mathrm{As}_{2} \mathrm{O}_{3}$ decreased the expression of GLI1, PTCH1 and n-Myc in vitro and in vivo.

Moreover, we found that GANT-61 (a GLI transcription inhibitor) simulated and enhanced the effects of $\mathrm{As}_{2} \mathrm{O}_{3}$ on sphere formation, apoptosis, and expression of GLI1, SOX2 and c-Myc in H446- or H209-derived CSCs. These results strongly suggested that Hedgehog signaling at least partially mediated the therapeutic effects of $\mathrm{As}_{2} \mathrm{O}_{3}$ on SCLC-derived CSCs. Our findings also agree with the data published by 
others. Fu et al. (43) showed that suppression of Hedgehog signaling by GANT-61 inhibited pancreatic CSCs growth in vitro and in null mice xenografts. Tong et al. (44) showed that GANT-61 induced apoptosis of prostate CSCs via a GLI-dependent mechanism. It has been reported that the transcription factor GLI1 could bind to the proximal promoter region of SOX2 and regulate SOX2 expression in primary melanoma cells (27) and in non-small cell lung cancer (NSCLC) $(45,46)$. Milla et al. (47) reported that the c-Myc gene was regulated by GLI1 in a zebrafish embryo model.

However, a phase II clinical trial of $\mathrm{As}_{2} \mathrm{O}_{3}$ (NCT01470248) recruited 17 patients with relapsed SCLC and found that $\mathrm{As}_{2} \mathrm{O}_{3}$ lacked effectiveness against tumor growth in SCLC patients and SCLC patient-derived xenografts (PDX) (48). One possible explanation for the lack of benefit is that due to the low percentage of CSCs in tumor tissues, $\mathrm{As}_{2} \mathrm{O}_{3}$ may be more potent when combined with cytotoxic therapy which kills the bulk differentiated tumor subpopulations. Just as Zheng et al. (19) reported that the combination of $\mathrm{As}_{2} \mathrm{O}_{3}$ and cisplatin was much more potent than either agent alone in SCLC cell line (H841) xenograft. Another possible explanation is that they adopted an intermittent regimen of drug administration to minimize hematologic toxicity as opposed to the daily continuous schedule performed in APL patients (49).

\section{Conclusions}

We found that CSCs were enriched from H446 and H209 SCLC cell lines using their ability to form tumor spheres in serum-free conditioned culture. $\mathrm{As}_{2} \mathrm{O}_{3}$ inhibited growth, induced apoptosis, and downregulated SOX2 and c-Myc expression in vitro and in vivo. SOX2 knockdown suppressed self-renewal and induced CSC apoptosis. GLI1 and its downstream genes PTCH1 and n-Myc were upregulated in SCLC-derived CSCs, and $\mathrm{As}_{2} \mathrm{O}_{3}$ reduced their expression in vitro and in vivo. GANT-61 (GLI inhibitor) mimicked and enhanced the changes in sphere formation, apoptosis, and gene expression induced by $\mathrm{As}_{2} \mathrm{O}_{3}$. Therefore, our study indicated a potential application for $\mathrm{As}_{2} \mathrm{O}_{3}$ in the treatment of SCLC via CSC targeting.

\section{Acknowledgments}

Funding: This work was supported by the National Natural Science Foundation of China (No. 81602618 and
81672929).

\section{Footnote}

Reporting Checklist: The authors have completed the ARRIVE reporting checklist. Available at http://dx.doi. org/10.21037/tlcr-20-467

Data Sharing Statement: Available at http://dx.doi. org/10.21037/tlcr-20-467

Conflicts of Interest: All authors have completed the ICMJE uniform disclosure form (available at http://dx.doi. org/10.21037/tlcr-20-467). The authors have no conflicts of interest to declare.

Ethical Statement: The authors are accountable for all aspects of the work in ensuring that questions related to the accuracy or integrity of any part of the work are appropriately investigated and resolved. The animal study was approved by the Committee on Ethics of Biomedicine, Second Military Medical University (Reference Number: 20160218-8160110302). Animal welfare and experimental procedures were carried out in accordance with the Guide for the Care and Use of Laboratory Animals (Ministry of Science and Technology of China).

Open Access Statement: This is an Open Access article distributed in accordance with the Creative Commons Attribution-NonCommercial-NoDerivs 4.0 International License (CC BY-NC-ND 4.0), which permits the noncommercial replication and distribution of the article with the strict proviso that no changes or edits are made and the original work is properly cited (including links to both the formal publication through the relevant DOI and the license). See: https://creativecommons.org/licenses/by-nc-nd/4.0/.

\section{References}

1. Gazdar AF, Bunn PA, Minna JD, et al. Small-cell lung cancer: what we know, what we need to know and the path forward. Nat Rev Cancer 2017;17:725-37.

2. Rossi A, Sacco PC, Sgambato A, et al. Optimal drugs for second-line treatment of patients with small-cell lung cancer. Expert Opin Pharmacother 2016;17:969-76.

3. Rodriguez E, Lilenbaum RC. Small cell lung cancer: past, present, and future. Curr Oncol Rep 2010;12:327-34. 
4. Bonnet D, Dick JE. Human acute myeloid leukemia is organized as a hierarchy that originates from a primitive hematopoietic cell. Nat Med 1997;3:730-7.

5. Sarvi S, Mackinnon AC, Avlonitis N, et al. CD133+ cancer stem-like cells in small cell lung cancer are highly tumorigenic and chemoresistant but sensitive to a novel neuropeptide antagonist. Cancer Res 2014;74:1554-65.

6. Eramo A, Lotti F, Sette G, et al. Identification and expansion of the tumorigenic lung cancer stem cell population. Cell Death Differ 2008;15:504-14.

7. Qiu X, Wang Z, Li Y, et al. Characterization of sphereforming cells with stem-like properties from the small cell lung cancer cell line H446. Cancer Lett 2012;323:161-70.

8. Watkins DN, Berman DM, Burkholder SG, et al. Hedgehog signalling within airway epithelial progenitors and in small-cell lung cancer. Nature 2003;422:313-7.

9. Park kS, Martelotto LG, Peifer M, et al. A crucial requirement for Hedgehog signaling in small cell lung cancer. Nat Med 2011;17:1504-8.

10. Szczepny A, Rogers S, WSN J, et al. The role of canonical and non-canonical Hedgehog signaling in tumor progression in a mouse model of small cell lung cancer. Oncogene 2017;36:5544-50.

11. Wu J, Ji Z, Liu H, et al. Arsenic trioxide depletes cancer stem-like cells and inhibits repopulation of neurosphere derived from glioblastoma by downregulation of Notch pathway. Toxicol Lett 2013;220:61-9.

12. Zhen Y, Zhao S, Li Q, et al. Arsenic trioxide-mediated Notch pathway inhibition depletes the cancer stem-like cell population in gliomas. Cancer Lett 2010;292:64-72.

13. Kozono S, Lin YM, Seo HS, et al. Arsenic targets Pin1 and cooperates with retinoic acid to inhibit cancerdriving pathways and tumor-initiating cells. Nat Commun 2018;9:3069.

14. Zhang KZ, Zhang QB, Sun HC, et al. Arsenic trioxide induces differentiation of CD133+ hepatocellular carcinoma cells and prolongs posthepatectomy survival by targeting GLI1 expression in a mouse model. J Hematol Oncol 2014;7:28.

15. Han JB, Sang F, Chang JJ, et al. Arsenic trioxide inhibits viability of pancreatic cancer stem cells in culture and in a xenograft model via binding to SHH-Gli. Onco Targets Ther 2013;6:1129-38.

16. Zheng CY, Lam SK, Li YY, et al. Arsenic trioxide-induced cytotoxicity in small cell lung cancer via altered redox homeostasis and mitochondrial integrity. Int J Oncol 2015;46:1067-78.

17. Pettersson HM, Pietras A, Munksgaard PM, et al. Arsenic trioxide is highly cytotoxic to small cell lung carcinoma cells. Mol Cancer Ther 2009;8:160-70.

18. Yang MH, Zang YS, Huang H, et al. Arsenic trioxide exerts anti-lung cancer activity by inhibiting angiogenesis. Curr Cancer Drug Targets 2014;14:557-66.

19. Zheng CY, Lam SK, Li YY, et al. Combination of arsenic trioxide and chemotherapy in small cell lung cancer. Lung Cancer 2013;82:222-30.

20. Chang KJ, Yang MH, Zheng JC, et al. Arsenic trioxide inhibits cancer stem-like cells via down-regulation of Gli1 in lung cancer. Am J Transl Res 2016;8:1133-43.

21. Stecca B, Ruiz iAA. A GLI1-p53 inhibitory loop controls neural stem cell and tumour cell numbers. EMBO J 2009;28:663-76.

22. Dontu G, Abdallah WM, Foley JM, et al. In vitro propagation and transcriptional profiling of human mammary stem/progenitor cells. Genes Dev 2003; $17: 1253-70$.

23. Lundholm L, Haag P, Zong D, et al. Resistance to DNA-damaging treatment in non-small cell lung cancer tumor-initiating cells involves reduced DNA-PK/ATM activation and diminished cell cycle arrest. Cell Death Dis 2013;4:e478.

24. Bartucci M, Svensson S, Romania P, et al. Therapeutic targeting of Chk1 in NSCLC stem cells during chemotherapy. Cell Death Differ 2012;19:768-78.

25. Tirino V, Desiderio V, Paino F, et al. Cancer stem cells in solid tumors: an overview and new approaches for their isolation and characterization. FASEB J 2013;27:13-24.

26. Gangemi RM, Griffero F, Marubbi D, et al. SOX2 silencing in glioblastoma tumor-initiating cells causes stop of proliferation and loss of tumorigenicity. Stem Cells 2009;27:40-8.

27. Santini R, Pietrobono S, Pandolfi S, et al. SOX2 regulates self-renewal and tumorigenicity of human melanomainitiating cells. Oncogene 2014;33:4697-708.

28. Zhang M, Rosen JM. Stem cells in the etiology and treatment of cancer. Curr Opin Genet Dev 2006;16:60-4.

29. Dean M, Fojo T, Bates S. Tumour stem cells and drug resistance. Nat Rev Cancer 2005;5:275-84.

30. Reynolds BA, Weiss S. Generation of neurons and astrocytes from isolated cells of the adult mammalian central nervous system. Science 1992;255:1707-10.

31. Abbaszadegan MR, Bagheri V, Razavi MS, et al. Isolation, identification, and characterization of cancer stem cells: A review. J Cell Physiol 2017;232:2008-18.

32. Fathi Maroufi N, Hasegawa K, Vahedian V, et al. A glimpse into molecular mechanisms of embryonic stem 
cells pluripotency: Current status and future perspective. J Cell Physiol 2020. [Epub ahead of print].

33. Zhang D, Tang DG, Rycaj K. Cancer stem cells: Regulation programs, immunological properties and immunotherapy. Semin Cancer Biol 2018;52:94-106.

34. Meng X, Li M, Wang X, et al. Both CD133+ and CD133subpopulations of A549 and H446 cells contain cancerinitiating cells. Cancer Sci 2009;100:1040-6.

35. Coppola D, Clarke M, Landreneau R, et al. Bcl-2, p53, CD44, and CD44v6 isoform expression in neuroendocrine tumors of the lung. Mod Pathol 1996;9:484-90.

36. Rudin CM, Durinck S, Stawiski EW, et al. Comprehensive genomic analysis identifies SOX2 as a frequently amplified gene in small-cell lung cancer. Nat Genet 2012;44:1111-6.

37. Peifer M, Fernandez-Cuesta L, Sos ML, et al. Integrative genome analyses identify key somatic driver mutations of small-cell lung cancer. Nat Genet 2012;44:1104-10.

38. Wang J, Wang H, Li Z, et al. c-Myc is required for maintenance of glioma cancer stem cells. PLoS One 2008;3:e3769.

39. Wang X, Huang Z, Wu Q, et al. MYC-Regulated Mevalonate Metabolism Maintains Brain Tumor-Initiating Cells. Cancer Res 2017;77:4947-60.

40. Hooper JE, Scott MP. Communicating with Hedgehogs. Nat Rev Mol Cell Biol 2005;6:306-17.

41. Kim J, Lee JJ, Gardner D, et al. Arsenic antagonizes the Hedgehog pathway by preventing ciliary accumulation and reducing stability of the Gli2 transcriptional effector. Proc Natl Acad Sci U S A 2010;107:13432-7.

42. Beauchamp EM, Ringer L, Bulut G, et al. Arsenic trioxide inhibits human cancer cell growth and tumor development in mice by blocking Hedgehog/GLI pathway. J Clin Invest 2011;121:148-60.

43. Fu J, Rodova M, Roy SK, et al. GANT-61 inhibits pancreatic cancer stem cell growth in vitro and in NOD/ SCID/IL2R gamma null mice xenograft. Cancer Lett 2013;330:22-32.

44. Tong W, Qiu L, Qi M, et al. GANT-61 and GDC0449 induce apoptosis of prostate cancer stem cells through a GLI-dependent mechanism. J Cell Biochem 2018;119:3641-52.

45. Bora-Singhal N, Perumal D, Nguyen J, et al. Gli1Mediated Regulation of Sox2 Facilitates Self-Renewal of Stem-Like Cells and Confers Resistance to EGFR Inhibitors in Non-Small Cell Lung Cancer. Neoplasia 2015;17:538-51.

46. Ooki A, Dinalankara W, Marchionni L, et al. Epigenetically regulated PAX6 drives cancer cells toward a stem-like state via GLI-SOX2 signaling axis in lung adenocarcinoma. Oncogene 2018;37:5967-81.

47. Milla LA, Cortes CR, Hodar C, et al. Yeast-based assay identifies novel Shh/Gli target genes in vertebrate development. BMC Genomics 2012;13:2.

48. Owonikoko TK, Zhang G, Kim HS, et al. Patient-derived xenografts faithfully replicated clinical outcome in a phase II co-clinical trial of arsenic trioxide in relapsed small cell lung cancer. J Transl Med 2016;14:111.

49. Chendamarai E, Ganesan S, Alex AA, et al. Comparison of newly diagnosed and relapsed patients with acute promyelocytic leukemia treated with arsenic trioxide: insight into mechanisms of resistance. PloS One 2015;10:e0121912.
Cite this article as: Chang KJ, Yin JZ, Huang H, Li B, Yang MH. Arsenic trioxide inhibits the growth of cancer stem cells derived from small cell lung cancer by downregulating stem cell-maintenance factors and inducing apoptosis via the Hedgehog signaling blockade. Transl Lung Cancer Res 2020;9(4):1379-1396. doi: 10.21037/tlcr-20-467 
A

>PSC55705-1-H1-

F_C09.ab1NNNNNNNTANAACTAAAGATTACAAAAACAAATTACAAAAATTCAAAATTTTCGGGT TTATTACAGGGACAGCAGAGATCCAGTTTGGTTAATTAATCGAGCGGCCGCCCCCTTCACCGA GGGCCTATTTCCCATGATTCCTTCATATTTGCATATACGATACAAGGCTGTTAGAGAGATAATT GGAATTAATTTGACTGTAAACACAAAGATATTAGTACAAAATACGTGACGTAGAAAGTAATAAT TTCTTGGGTAGTTTGCAGTTTTAAAATTATGTTTTAAAATGGACTATCATATGCTTACCGTAACT TGAAAGTATTTCGATTTCTTGGCTTTATATATCTTGTGGAAAGGACGAAACACCGGCAGCTCG CAGACCTACATGAACTCGAGTTCATGTAGGTCTGCGAGCTGTTTTTAATTCTCGACCTCGAGA CAAATGGCAGTATTCATCCACGGATCCTAACCCGTGTCGGCTCCAGATCTGGCCTCCGCGCC GGGTTTTGGCGCCTCCCGCGGGCGCCCCCCTCCTCACGGCGAGCGCTGCCACGTCAGACG AAGGGCGCAGCGAGCGTCCTGATCCTTCCGCCCGGACGCTCAGGACAGCGGCCCGCTGCT CATAAGACTCGGCCTTAGAACCCCAGTATCAGCAGAAGGACATTTTAGGACGGGACTTGGGT GACTCTAGGGCACTGGTTTTCTTTCCAGAGAGCGGAACAGGCGAGGAAAAGTAGTCCCTTCT CGGCGATTCTGCGGAGGGATCTCCGTGGGGCGGTGAACGCCGATGATTATATAAGGACGCG CCGGGTGTGGCACAGCTAGTTCCGTCGCAGCCGGGATTTGGGTCGCGGTTCTTGTTTGTGGA TCGCTGTGATCGTCACTTGGTGAGTAGCGGGCTGCTGGGCTGGCCGGGGCTTTCGTGGCCG CCGGGCCGCTCGGTGGGACGGAAGCGTGTGGAGAGACCGCCAAGGGCTGTAGTCTGGGTC CGCGAGCAAGGTTGCCCTGAACTGGGGGTTGGGGGGAGCGCAGCAAATGGCGGC

shSOX2-1 (F) ccggcaGCTCGCAGACCTACATGAActcgagTTCATGTAGGTCTGCGAGCtgttttg

B

>PSC55706-1-H1-

F A08.ab1NNNNNNNNACAAACTAAAGATTACAAAAACAAATTACAAAAATTCAAAATTTTCGGG TT̄TATTACAGGGACAGCAGAGATCCAGTTTGGTTAATTAATCGAGCGGCCGCCCCCTTCACCG AGGGCCTATTTCCCATGATTCCTTCATATTTGCATATACGATACAAGGCTGTTAGAGAGATAAT TGGAATTAATTTGACTGTAAACACAAAGATATTAGTACAAAATACGTGACGTAGAAAGTAATAA TTTCTTGGGTAGTTTGCAGTTTTAAAATTATGTTTTAAAATGGACTATCATATGCTTACCGTAAC TTGAAAGTATTTCGATTTCTTGGCTTTATATATCTTGTGGAAAGGACGAAACACCGGGAAGAAG GATAAGTACACGCTCTCGAGAGCGTGTACTTATCCTTCTTCTTTTTAATTCTCGACCTCGAGAC AAATGGCAGTATTCATCCACGGATCCTAACCCGTGTCGGCTCCAGATCTGGCCTCCGCGCCG GGTTTTGGCGCCTCCCGCGGGCGCCCCCCTCCTCACGGCGAGCGCTGCCACGTCAGACGAA GGGCGCAGCGAGCGTCCTGATCCTTCCGCCCGGACGCTCAGGACAGCGGCCCGCTGCTCAT AAGACTCGGCCTTAGAACCCCAGTATCAGCAGAAGGACATTTTAGGACGGGACTTGGGTGAC TCTAGGGCACTGGTTTTCTTTCCAGAGAGCGGAACAGGCGAGGAAAAGTAGTCCCTTCTCGG CGATTCTGCGGAGGGATCTCCGTGGGGCGGTGAACGCCGATGATTATATAAGGACGCGCCG GGTGTGGCACAGCTAGTTCCGTCGCAGCCGGGATTTGGGTCGCGGTTCTTGTTTGTGGATCG CTGTGATCGTCACTTGGTGAGTAGCGGGCTGCTGGGCTGGCCGGGGCTTTCGTGGCCGCCG GGCCGCTCGGTGGGACGGAAGCGTGTGGAGAGACCGCCAAGGGCTGTAGTCTGGGTCCGC GAGCAAGGTTGCCCTGAACTGGGGGTTGGGGGGAGCGCAGCAAATTG

shSOX2-2 (F) ccgggaAGAAGGATAAGTACACGCTctcgagAGCGTGTACTTATCCTTCTtcttttg

Figure S1 Sequencing results of shSOX2-1 (A) and shSOX2-2 (B). The first paragraph was the sequencing results of positive clone after PCR identification, and the second paragraph was the shSOX2 sequence. Sequencing results confirmed that the inserted shRNA sequence was correct. 
Table S1 Primer sequences were as follows

\begin{tabular}{lll}
\hline Gene & 5'-3'Forward & 5'-3'Reverse \\
\hline NANOG & AAGGTCCCGGTCAAGAAACAG & CTTCTGCGTCACACCATTGC \\
OCT4 & AGTGAGAGGCAACCTGGAGA & GCCGGTTACAGAACCACACT \\
soX2 & GCTGCTTAGACGCTGGATTT & CTCCTCCTCGTCGCAGTAGA \\
$\beta$-actin & TACCTCTTCCTCCCACTCCA & GGGACATGTGAAGTCTGCTG \\
\hline
\end{tabular}

